\title{
WestVirginiaUniversity
}

THE RESEARCH REPOSITORY @ WVU

Graduate Theses, Dissertations, and Problem Reports

2015

\section{How History Matters: Polish Memory Politics and Policies Toward Russia Since 1989}

Richard Tyler Underwood

Follow this and additional works at: https://researchrepository.wvu.edu/etd

\section{Recommended Citation}

Underwood, Richard Tyler, "How History Matters: Polish Memory Politics and Policies Toward Russia Since 1989" (2015). Graduate Theses, Dissertations, and Problem Reports. 6849.

https://researchrepository.wvu.edu/etd/6849

This Thesis is protected by copyright and/or related rights. It has been brought to you by the The Research Repository @ WVU with permission from the rights-holder(s). You are free to use this Thesis in any way that is permitted by the copyright and related rights legislation that applies to your use. For other uses you must obtain permission from the rights-holder(s) directly, unless additional rights are indicated by a Creative Commons license in the record and/ or on the work itself. This Thesis has been accepted for inclusion in WVU Graduate Theses, Dissertations, and Problem Reports collection by an authorized administrator of The Research Repository @ WVU. For more information, please contact researchrepository@mail.wvu.edu. 


\title{
How History Matters: \\ Polish Memory Politics and Policies Toward Russia Since 1989
}

\author{
Richard Tyler Underwood \\ Thesis submitted \\ to the College of Arts and Sciences \\ at West Virginia University \\ in partial fulfillment of the requirements for the degree of \\ Master of Arts \\ in \\ History
}
Robert Blobaum, Ph.D., Chair Joe Hagan Ph.D. Joseph Hodge Ph.D.
Department of History
Morgantown, West Virginia
2015

Keywords: Central and Eastern Europe; Memory; Poland; Russia; Monuments;

Katyn,

Copyright 2015 Richard Tyler Underwood 


\title{
ABSTRACT \\ How History Matters: \\ Polish Memory Politics and Policies Toward Russia Since 1989
}

\author{
Richard Tyler Underwood
}

This thesis examines how memory can affect international relations and vice versa. In order to examine how memory can affect international relations the relationship between Poland and the Russian Federation since 1989 is analyzed as well as how their pasts and the period of Soviet dominance affects this relationship. This thesis focuses on two specific modes of memory: the Katyn Forest Massacre and Soviet monuments and memorials in Poland, specifically the Polish-Russian Brothers in Arms monument. Looking at these modes of memory and specific cases through a constructivist perspective will exemplify how memory plays a role in international relations. At the same time, this thesis examines how more recent developments in the Polish-Russian relationship, including their conflicting positions over Ukraine, have shaped historical memory. In its emphasis on the role of memory in the Polish-Russian bilateral relationship, this thesis thus contributes to both international relations and history. 
Funding for my thesis and my MA studies at West Virginia University, Collegium Civitas, and the University of Tartu was made possible by the Transatlantic MA Program in East-Central European Studies, an "Atlantis" project sponsored by the Fund for the Improvement of Secondary Education of the U.S. Department of Education and the European Commission's Executive Agency for Education, Audiovisual and Culture. 


\section{TABLE OF CONTENTS}

INTRODUCTION: An Amalgamation of Memory and Policy $\ldots \ldots \ldots \ldots \ldots \ldots \ldots \ldots \ldots$

CHAPTER 1: Poland's Policies Toward Russia after 1989........................13

I. Can Memory Affect Foreign Policy? .............................................13

II. Poland's Policies Toward Russia after 1989 ...........................16

III. Polish-Russian Relations over East-Central Europe....................19

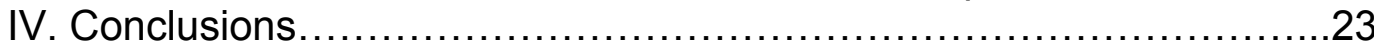

CHAPTER 2: The Katyń Forest Massacre ......................................25

I. Background and "The Katyń Lie"....................................26

II. Contention and Need for an Apology .......................................

III. Andrzej Wajda's Katyń ................................................ 37

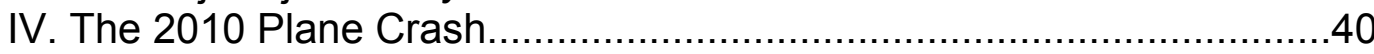

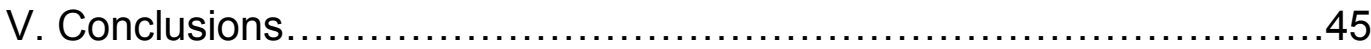

CHAPTER 3: Soviet Monuments and Memorials in Poland.......................47

I. Monuments, Memorials, and Memory ...............................47

II. Background and Soviet Monuments After 1989.......................50

III. Warsaw's Monument of Polish-Soviet Comradeship.....................58

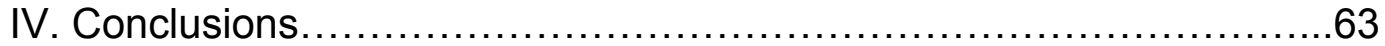

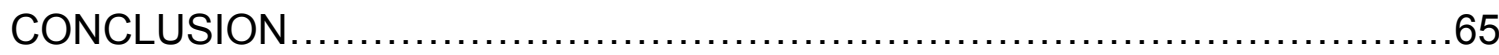

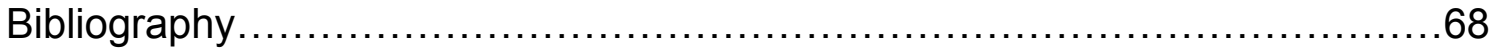




\section{Introduction: An Amalgamation of Memory and Policy-A Constructivist Approach}

Poland and its eastern neighbor, contemporarily the Russian Federation and before that the Soviet Union, have had a close and often contentious relationship, particularly over the last century. This relationship has shaped and driven memory, identity, and politics throughout the century and continues to shape these phenomena in contemporary Poland. Since Poland's liberation from Soviet influence in 1989 the debate on how to handle the past and the political relationship with the Soviet Union, and with the Russian Federation that succeeded it, has always been a priority and discussion in Polish policies and politics. The Soviet Union up to 1991 and then the Russian Federation since 1991 have also taken steps since 1989 in order to come to terms with past Soviet crimes and to keep their relationship in tact with the countries of Central and Eastern Europe while attempting to maintain their sphere of influence in the former Soviet republics of Belarus and Ukraine.

Leftovers and reminders of the past like monuments, graves, and even names of streets and buildings have become subjects of debate in Poland in deciding what to do with reminders of what for many are offensive or are symbols of oppression. Past events between Poland and the Soviet Union like the Katyń Forest Massacre have been debated, portrayed in film and song, taken to court, and have even found some points of resolution and reconciliation since 1989. Dealing with the wrongs of the past is something that most countries must address at some point, yet the era of communism, Stalinism and Soviet crimes 
remains unique to Central and Eastern Europe and is handled differently between the Russian Federation and each individual state. As time continues there have been some periods where reconciliation has proved more feasible than others, as it was for Poland and the Russian Federation between 20072010. As memory politics do not happen in a vacuum often times international politics come to play a role in how the memory of the past is created. The continued conflicts over Ukraine between Poland and the Russian Federation are important in the overall context of memory because of the role in which these external politics spill over into memory politics. In short memory can influence international politics but international politics can also shape memory.

History, memory, and identity certainly play a major role in how Poland perceives the Russian Federation and tends to look back at the communist era of Soviet domination and influence. In fact, the memory of the Soviet Union and its actions dominates discussions of the past between Poland and Russia, and often reflects the current Russian-Polish relations. Some parties in Poland, specifically right-wing parties such as the Law and Justice Party (PiS), by recalling the Soviet past for domestic consumption, are more vocal about in their demands for restitution and compensation from the Russian Federation. Other Polish organizations such as the Center for Polish-Russian Dialogue of Understanding (Powstanie Centrum Polsko-Rosyjskiego Dialogu i Porozumienia) seek to move beyond the past to forge a new relationship with the Russian Federation. These conflicts and debates within Poland raise questions about how collective memory 
is portrayed, both domestically and in relations with the Russian Federation. ${ }^{1}$ Collective memory is often utilized, and many times abused, in Polish domestic politics when dealing with the Russian Federation.

Aleida Assmann points out that "Collective memory is particularly susceptible to politicized forms of remembering," and this is certainly the case in Poland as seen by right-wing groups' politicization of historical events like the Katyń Forest Massacre. ${ }^{2}$ Collective memory is a key component of a state or a group's collective identity and in reference to Poland one can refer to these connective memories as national memory and national identity. ${ }^{3}$ These collective memories are "re-embodied" and transmitted through generations because of their importance to national identity, also referred to as a "meta-memory", or a memory of a memory. ${ }^{4}$ In sum, these memories define for many Poles who they are and what their nation represents and also shape the national historical narrative. This collective memory is not only expressed in identity but can also create bonding myths that hold the nation together. Collective memory creates a sense of unity among those who remember, in this case the Poles, and "holds them inwardly together" through the sharing of a "common point of view" known as connective memory or connective bonding memory. ${ }^{5}$

${ }^{1}$ Collective memory as defined by Sontag, “...groups indeed define themselves by agreeing upon what they hold to be important, to which story they accord eminence, which anxieties they share." Aleida Assman, "Transformations between History and Memory," Social Research, vol. 75, no. 1(2008): 52.

2 Jan Assman. Religion and Cultural Memory: Ten Studies (Stanford: Stanford University Press, 2006), 7.

${ }^{3}$ Ibid, 6-7.

4 Aleida Assman, 56. 
Connective bonding memory does, however, have problematic tendencies when facing the "wrong doings" of the past. This is part of the connective bonding that can cause troubled relationships with those who in the past have wronged another group. Naturally, people cannot forget tragic events that bond them together and this can cause emotional outcries or demands for justice, sometimes even overstepping the very definition of justice by calling for vengeance. Connective memory can hold the nation together but can also push it away from international cooperation and cause contention instead.

When analyzing memory politics between Poland and the Russian Federation it is imperative that the context of the relationship be discussed, and in this regard the method to analyze it, derived from the theoretical model of constructivism, is crucial. This, in chapter 1 , we will discuss the essential context for how memory plays a role in foreign policy and vice versa. Therefore, it is necessary to analyze Poland's foreign policy since 1989 looking at how Poland has played a major role in the Central and Eastern European transition from Soviet influence and how the Polish-Soviet and Polish-Russian relationship has changed since Poland's recovery of state sovereignty. Because of the role accorded to identity in constructivist theory, taking a constructivist approach at examining the Polish and Russian states rather than looking solely at the international system can further explain how these states interact and how memory plays such a vital role in their political relationship. Furthermore it is important to not just rely on identity when utilizing constructivism to predict or

\footnotetext{
5 Jan Assmann, 11.
} 
explain a state's actions but also the collective memories that have built that identity. Moreover, one must take into account the importance and role that Ukraine and more generally the borderlands between Poland and Russia have been to the Polish-Russian relationship since conflicts over them often activate and aggravate memory politics. However, the main purpose of this section is to exemplify just how crucial memory politics are in the relationship of Poland and the Russian Federation and how these memory politics can in turn have an affect on Poland's foreign policy toward Russia and vice versa. With this historical context and understanding of Poland's motives and foreign policy strategies we can then examine several aspects of memory and memory politics in Poland.

In chapter 2 we will see that in memory politics "Political cults of the dead play a particularly disastrous role in such conflicts," and this can be seen looking at the Katyń Forest Massacre, one of the most important events in modern Polish history, identity, collective and connective bonding memory. ${ }^{6}$ It is essential in examining how this event and the Soviet Union and the Russian Federation's actions in its aftermath have played a role in memory politics because of its importance to the Polish nation. The Katyń Massacre has many layers since the event has been covered up, lied about, and falsely depicted during the Soviet era and then addressed and even partially resolved during the last two decades, leading to opportunities for reconciliation. It is also important to examine Polish the Katyń massacre in the context of Polish domestic politics and it has been manipulated by some right-wing groups for political gain. Recent events,

\footnotetext{
${ }^{6}$ Jan Assman, 21.
} 
especially the plane crash near the Katyń forest in 2010 killing many top Polish government officials, including the President, will serve as an example of rehashing memories in domestic politics and using the crash for political aggrandizement on the one hand, but also as another opportunity for reconciliation as a consequence of the Russian Federation's expressions of condolence. Since Katyń and the duration of the conflict over it have played such a pivotal role in Polish-Russian relations and memory politics, it is an essential piece of the puzzle requiring examination and analysis.

Finally, discussion of monuments as sites of memory in public spaces in chapter 3 is important to exemplify the conflicting narratives seen in Poland set through a different sphere. Taking into account the context developed in chapter 1 we will see how the fate of Soviet monuments in Poland have affected and continue to affect both Poland and Russia's foreign policy. Looking at how changing, relocating, or destroying monuments and memorials has challenged the relationship with the Russian Federation and caused tension domestically is essential to understanding the importance of memory politics. Looking at several monuments like the Gratitude to the Red Army monument in Legnica or the Red Army monument that was moved to a cemetery in Kraków will give clear examples of how Soviet monuments have been handled in Poland since 1989. Focusing on the Polish-Soviet Comradeship Monument in Warsaw will give a more precise case study and is a good example of memory politics because of the recent nature of its contention in Polish-Russian relations, the location of the monument in the capitol city of Poland, and the international attention that the 
removal of the monument has gathered. These examples of monuments and memory in public spaces will illustrate just how important memory politics are in Poland, how they are connected with identity, and how they affect state policies.

Examining Poland from a constructivist view while looking at two aspects of memory, about a specific event and its aftermath on the one hand, and monuments and memorials on the other, combines approaches to the past and memory as well as to the politics and policies that have defined the PolishRussian relationship since 1989. This perspective further explains how these two states behave in the international system and how identity and therefore memory come into to play in international relations. However, the constructivist view with its emphasis on identity somewhat neglects the significance of memory and how it affects identity and thus plays a role in international relations. Utilizing many primary sources, including the Polish, Russian and English-language press, polls, court cases, and the relevant secondary literature in international relations and history will support the constructivist approach with bottom-up perspectives from both Poland and Russia of their relationship. Works by Joanna Gorska and Rick Fawn have analyzed Poland's policy toward Russia up to the mid and late 2000 's with case studies, but the role of memory, which has become particularly important since 2009 , needs to be exemplified. ${ }^{7}$ As we will see $2007-2010$ serves as important years of reconciliation between Poland and the Russian Federation, while Ukraine has played an important role in the deterioration of the relationship in 2004 and again in 2014. These years of reconciliation, which punctuate two

\footnotetext{
7 Joanna A. Gorska, Dealing with a Juggernaut: Analyzing Poland's Policy Towards Russia, 1989-2009 (Lexington Books, 2012)
} 
periods of tension over Ukraine, are essential when speaking about memory politics between the two states and are missing in the literature and context of Polish-Russian memory politics. It is evident that collective memory and identity play a major role in Poland and will continue to influence memory politics. Showing that history and the past does matter when looking at states in the international system can further explain Poland's policies and the relationship between Poland and the Russian Federation. 


\section{Chapter 1: Poland's Policies Toward Russia after 1989}

Various Polish and Russian state entities have had interactions for centuries and these ties have not often been cordial. The interactions from the last century alone have been defined by two devastating wars and a fifty-year dominance of Poland by the Soviet Union, the predecessor of the Russian Federation. As Poland celebrates twenty-five years of freedom the memory of this fifty-year dominance by the Soviet Union overshadows any other previous history in this area and often affects and has certainly played a major role in Polish policy toward Russia since the round table talks in 1989. As we will see memory is often shaped by these relations and vice versa.

\section{CAN MEMORY AFFECT FOREIGN POLICY?}

Memory in a state is often shaped by foreign policies or actions of another state. However, memory is not only subject to international relations but can also affect foreign policy and international relations in its own right. Memory represents past actions, historical and political, between two actors and the collective memories of two actors can either bond them closer together or drive them apart. Collective memory is often integrated with the circumstances of the present and makes up a collective or national identity and therefore memory should be viewed and explained through a constructivist perspective. "The identity of a state implies its preferences and consequent actions," meaning that the interests of a state are often a product of how that state identifies itself. Thus,

\footnotetext{
8 Jan Assmann, 6-7.
} 
in turn, a state's identity is shaped by collective or national memory. ${ }^{9}$ Integrating national or collective memory into the preferences and actions of a state goes beyond national identity and provides a more specific account of why certain states like Poland and the Russian Federation act a certain way toward one another.

"National Identity" in political science is often associated with symbols and a group of people being tied together through these symbols when faced with a crisis or threat. ${ }^{10}$ This can be an outcome of identity, but more specifically important is the role that memory plays in shaping identity and how critical events affect policy goes deeper than symbols unifying a group behind a response. Memory and identity play a major role in examining cooperative or noncooperative foreign policy with a state, but memory can also help explain polices like the removal of Soviet monuments, which could enhance the security risk to a Central or Eastern Europe state from the Russian Federation. This policy may not make sense in terms of rational political calculations: Why would a state remove a statue if this action could result in an international security risk? Thus, memory is integrated with identity, but it goes beyond playing a role in explaining the systemic structure in which states behave in certain ways towards other states in the international system. Memory also plays a role in domestic politics, as we will see in examples drawn from Poland, which in turn can affect international politics and polices.

\footnotetext{
${ }^{9}$ Ted Hopf, "The Promise of Constructivism in International Relations Theory," International Security, Vol. 23 (1998), 176.

${ }^{10}$ William Bloom, Personal Identity, National Identity and International Relations (Cambridge: Cambridge University Press, 1990), 52.
} 
Of course one must look at how realism in international relations theory was supplanted by this constructivist view of how states interact, particularly in regards to state security. After 1991 when the Soviet Union collapsed the international system was no longer a bipolar system with two states seeking hegemony. The system rather became a unipolar system with the United States as the hegemon in the international system. As time elapsed the international system became multi-polar rather than bi-polar or multi-polar with many great power states therefore making the system much more unpredictable and anarchic.

The dominance of the realist view of states always pursing power politics was challenged after the Cold War ended. ${ }^{11}$ One can still apply, however, the notion defensive realism to post-cold war Central and Eastern Europe. These were subordinate states that had relied on the Soviet Union for defense and with the Soviet Union gone these states faced a major security dilemma. In the 1990's, for example, Poland did not want to provoke Russia, which was still a strong power in the region, and this was reflected in its non-confrontational foreign policy, including the agreement in the early 1990's to not remove any more Soviet monuments. During this period Poland wanted to seek security outside of its dependence on Russia. After Poland joined North Atlantic Treaty Organization (NATO) in 1999 Russia posed less of a security threat to Poland and in turn Polish foreign policy toward Russia became less cooperative as we will see in examples of Soviet monuments and how Poland has handled the

\footnotetext{
11 Jack L Snyder, Myths of Empire: Domestic Politics and International Ambition (New York: Cornell University Press, 1991), 11.
} 
Katyń Massacre in relation with Russia. ${ }^{12}$ These examples of first cooperative policy implemented and later a non-cooperative policy taken toward Russia is how defensive realism within a constructivist framework was visible during this period.

\section{POLAND'S POLICIES TOWARD RUSSIA AFTER 1989}

Some background is necessary in order to contextualize how the two examples of collective memory from the era of communist rule and Soviet domination in Poland fit into the post-1989 Polish-Russian relationship. The historical context and framework is essential to understanding how memory and identity in turn affect the relationship between two states, whether in the case of Poland or the other former communist states in Eastern and Central Europe.

Polish foreign policy should be divided into four periods since 1989. From 1989 until the break up of the Soviet Union in 1991 Poland was trying to further break free from the dominant Soviet influence while still maintaining a relationship with the Soviet Union. After the round table talks that brought about the end of communist rule in 1989, Poland sought to reassert its sovereignty and defend its interests in the rapidly changing area of Central and Eastern Europe. ${ }^{13}$ Domestic politics and policies became the major focal point of political discussions and debates within Poland but international relations, particularly with the West, were also important for the newly independent country. Balancing

\footnotetext{
12 Gorska, 16.

${ }^{13}$ Rick Fawn, Ideology and National Identity in Post-Communist Foreign Policies (London: Frank Cass Publishers, 2004), 194.
} 
a relationship between the Soviet Union, the West, states with similar pasts in the Soviet bloc within the region also became a key focus of Polish policy.

From the break-up of the Soviet Union in 1991 until the NATO invitation to join the organization in 1997, Poland's foreign policy focused on security. During this period Poland was wary of political instability in the Russian Federation and the Russian threat remained a high priority. ${ }^{14}$ In 1991 Poland along with Hungary and Czechoslovakia formed the Visegrad group, which brought the three former communist states together in order to enhance regional security. ${ }^{15}$ Poland also focused on developing a cooperative relationship with the West particularly with France and newly unified Germany. ${ }^{16} \mathrm{~A}$ focus on Atlanticism also became important in order to establish more security for the state and to distance Poland from the Russian Federation. Poland even joined talks with the North Atlantic Cooperation Council (NACC) in 1991 in hopes of joining NATO at some future point. ${ }^{17}$

The next period of the change in Polish foreign policy can be seen from 1997, when Poland was invited to join NATO (which it did formally in 1999) until several years after the big bang enlargement in 2004 when Poland and many other Central and Eastern European countries joined the European Union. This period firmly anchored Poland in the security structures of the West and suppressed the uncertainty and fear coming from Russia. Some cooperation can

\footnotetext{
14 Ibid, 195.

15 "History of the Visegrad Group," VisegradGroup.eu.

${ }^{16}$ Fawn, 194.

17 "The North Atlantic Cooperation Council (NACC) (archived)," NATO.int October, 20 2011.
} 
even be seen from Russia as they begrudgingly signed the Paris treaty with NATO agreeing that Poland could join the organization. ${ }^{18}$ This period was a pivotal point for Poland as many of the uncertainties over security and stability were laid to rest, giving Poland an opportunity to focus more on its economy and trade.

Poland still largely follows the same policies that characterized the period of NATO accession, however, several years after accession into the European Union there has been growing evidence of some Euroscepticism, economic slowdown if not outright recession, and growing concerns growing about security in reference to a more assertive Russian Federation. These aspects define the present-day Republic of Poland and how both its domestic policies and outside influences have come to affect its international relationships and polices toward Russia. Conservative groups formed in the early 2000's around the time of Poland's joining the European Union, including the Law and Justice Party (PiS) that seeks E.U. cooperation in some regards, but wants to assert its version of Polish national interests and more hardline policies toward Russia, though not always consistently (for example, PiS is not as willing to confront Russia over Ukraine, even if it champions the elimination of Soviet-era monuments). The years 2007-2010 showed signs of reconciliation between Poland and the Russian Federation through the public commemorations for the victims of past Soviet crimes and a more open dialogue toward one another. More recent events like Russia's military involvement in Ukraine and economic sanctions have only

\footnotetext{
18 "Yeltsin in Paris to sign NATO Agreement," CNN News, May 26, 1997.
} 
caused Poland more security risks, but has also allowed Poland to become a key actor in a region disputed between Moscow and the West. ${ }^{19}$

\section{POLISH-RUSSIAN RELATIONS OVER EAST-CENTRAL EUROPE}

When speaking about Polish and Russian relations their relationship with other states, particularly Ukraine, in the area of Eastern Europe are imperative to discuss. This area has been a constant battleground and has been problematic for Polish-Russian relations from the time of the Polish-Lithuania commonwealth to the present. Geography, memory of these conflicts, and the simultaneous reemergence of Russian and Polish influence in Ukrainian politics is important in the overall context of Polish-Russian relations and the memory politics that coincide with them.

Since 1989 the influence of Poland in neighboring states to its east builds on a history that began during the Middle Ages. Poland's main interests between 1989-1991 were integration with the West, stabilizing its eastern borders, and the protection of Polish minorities in neighboring states ${ }^{20}$ After 1991 Poland not only wanted to protect ethnic Polish minorities in Ukraine, Belarus, and Lithuania but also preserve the independence of these states against future Russian Imperialism. Poland began defining and introducing new norms with minority treaties, since the West did not have minority standards or protections yet, with Ukraine, Belarus, and Lithuania and started the "Europeanization" of the area

\footnotetext{
19 "Don't Forget About Russia's Invasion and Occupation of Crimea," The Washington Post, August 28, 2014.

20 Timothy Snyder, Reconstruction of Nations: Poland, Ukraine, Lithuania, Belarus, 1569-1999 (Yale: Yale University Press, 2003), 257.
} 
before the rest of Europe was aware a need to do so. ${ }^{21}$ Poland called these "European Standards," by which it meant the "territorial integrity of non-nation states and the protection of the cultural rights of minorities." ${ }^{22}$ The Polish approach of "European Standards" was quite different than the approach that the Russian Federation, and the Soviet Union before it, had toward these countries. The Russian Federation had a preconceived notion that these areas, particularly Belarus and Ukraine, were in a sense Russian lands because of their "descent" from the medieval East Slavic state of Kyivan Rus'. ${ }^{23}$

In 1992 Poland and Russia again took different approaches when dealing with minorities in Ukraine. Poland recognized Ukraine as well as its western borders and asserted itself as a status quo power in Eastern Europe, agreeing not to intervene in Ukraine over Polish minority concerns. Russia on the other hand had a different approach, with Yeltsin deciding that the eastern borders of Ukraine would have to be redrawn, particularly in regards to the area of Crimea, while many Russian politicians refused to recognize Ukraine as a state at all. ${ }^{24}$ Poland continued to act as a key supporter of the region's states during the 1990's in meetings with Western countries, like the United States in 1993, to emphasize the importance of integrating Ukraine with the West. Although the Russian Federation was weakened during this period in the aftermath of the post-Soviet economic and political crises, Poland did not want to cause conflict

\footnotetext{
${ }^{21}$ Ibid, 258.

22 Ibid, 257.

${ }^{23}$ Historically Ukraine and Belarus became parts of the Polish-Lithuania Commonwealth after the disintegration of Kyivan Rus'. Ibid, 261.

${ }^{24}$ Ibid, 264-265.
} 
with the Russian Federation. However, Poland was able to gain more influence in the region and even sign new energy agreements with both the Russian Federation and Ukraine. The relationship of the Ukraine and Poland continued to flourish in the 1990's and Poland continued to be a major player in Eastern Europe.

Polish-Russian interests in Eastern Europe came into conflict again in 2004 during the Ukrainian Presidential elections. Poland came out publicly supporting one candidate, Yushchenko, while Russia publicly supported the other, Yanukovych. Both Russia and Poland had much at stake in the election as Yushchenko was a pro-Western candidate and Yanukovych was a pro-Russian candidate. Thus the candidate who won the election would strengthen ties with one side and weaken those with the other, whether it be Poland or Russia. These elections became quite controversial as the pro-Russian forces manipulated the election using the Prime Minister's power as well as the President's influence to manipulate the media and use the power of the state to Yanukovych's advantage ${ }^{25}$ After the suspect victory of Yanukovych in the runoff election and Yushchenko's finally victory in the third vote, Polish President Kwasniewski stepped in to mediate tensions and to push Ukrainian president Kuchma to accept the results of the final election. Kuchma with the backing of Russia refused. ${ }^{26}$ The results and actions of the Ukrainian president brought about the "Orange Revolution" to Ukraine, preceded by unrest and protests. The Russian

\footnotetext{
${ }^{25}$ Minton F. Goldman, "Polish-Russian Relations and the 2004 Ukrainian Presidential Elections," East European Quarterly, XL No 4 (2006),413.

${ }^{26}$ Ibid, 417.
} 
Federation perceived Poland's, as well as the European Union's, actions as intrusive and many in the Kremlin blamed Poland for the Orange Revolution. The 2004 elections and the Orange Revolution put a major strain on Polish-Russian relations with the Russian Federation issuing embargos, raising gas prices, and demanding an apology from Poland. ${ }^{27}$

Tensions over Ukraine erupted again in 2013 as President Yanukovych, restored to power through his electoral victory in 2010, refused to sign an association treaty with the EU much promoted by Poland and instead accepted a Ioan from Russia to promote economic development. ${ }^{28}$ Protests became more violent as time progressed until President Yanukovych was forced out of presidency and an interim government was placed in control in February 2014. Again, Poland and Russia found themselves on opposing sides; the Russian Federation refused to acknowledge the interim government and viewed this revolution as a coup d'état while Poland viewed this revolution as political justice, democracy, and liberation from an oppressive and corrupt government. During the interim government the Russian Federation annexed Crimea and a counterrevolution began in Eastern Ukraine. ${ }^{29}$ The annexation of Crimea fueled international outrage, causing many countries, including the United States and many European Union states, including Poland, to approve economic sanctions against the Russian Federation. In response, the Russian Federation imposed

\footnotetext{
27 lbid, 422.

28 "Ukraine Protests After Yanukovych EU Deal Rejection," BBC News, November, 30 2013.

29 "Ukraine's Revolution: Making Sense of a Year of Chaos," BBC News, November 21, 2014.
} 
sanctions on these Western countries as well. The Ukrainian revolution and conflict put new strains on the Polish-Russian relationship, which had seen improvement and reconciliation just three years previously.

Poland and the Russian Federation have always been key actors in Europe's "Eastern neighborhood" and have fought wars over it, most recently in the Polish-Soviet war of 1919-1921, which resulted in the partition of Ukraine between them. This butting of heads, so to speak, over the lands between them affects not only the countries economically and geographically, but often affects memory politics making reconciliation difficult. Thus, these actions and policies are important to the overall context of memory politics in order to fully understand how memory politics are affected by both the past and by the current state of international relations.

\section{CONCULSIONS}

Collective memory is derived from past actions between states and is important to examine when looking at the international system. Collective memory and identity make a state more predictable and can explain or predict how a state will act. Therefore it is imperative to take a constructivist view of Polish-Russian relations.

This historical framework of Poland's past policies and the assertion of its sovereign interests since regaining its independence from Soviet domination as well as the role of Eastern Europe in Polish-Russian relations are important to keep in mind when analyzing the important aspects of memory featured in the next two chapters. These chapters will now explain in more detail the historical 
context that has affected Poland's foreign policy towards the Russian Federation through memory politics as well as exemplify how foreign policy has shaped memory. 


\section{Chapter 2: Memory of The Katyń Forest Massacre}

Throughout Poland, the scar left by the Katyń Forest Massacre is evident in monuments, television programs, songs, films, and the yearly anniversary of the massacre. The memory of the tragedy of the Katyn Forest Massacre is passed down through generations and has even survived an oppressive regime's distorted portrayal of the massacre. In Poland the word "Katyń" has become equally as emotionally charged as words like "Holocaust" or "Siberia." The Katyń Forest Massacre has even been brought before The European Court Of Human Rights, which both Poland and Russia agreed to join by signing the European Convention on Human Rights. ${ }^{30}$ The Katyń Forest Massacre plays an important role in Polish memory politics as the massacre is embedded deep in the Polish psyche and a part of Polish identity that transcends generations and serves as a form of connective memory. The Katyń Forest Massacre is one of the most important topics when discussing Polish-Russian relations because of the contentious history of the event, the role memory of that event plays within Polish society as a kind of connective bonding memory, and the ways in which "Katyń" has become utilized for domestic political gain. This connective memory bonds the nation as victims and has become important enough to be forever embedded in Polish national memory. However, this collective memory not only affects

\footnotetext{
${ }^{30}$ A treaty made by the Council of Europe in order to protect human rights and fundamental freedoms in Europe. All members of The European Court of Human Rights must sign this treaty. "Convention for the Protection of Human Rights and Fundamental Freedoms," Council of Europe.
} 
Poland's relationship with the Russian Federation, but often becomes highly politicized within Poland itself and has been used to mobilize and recruit political constituencies and to oppose others. The Katyń Massacre is one of the most important events when analyzing memory politics and conflicting narratives in Poland because of its implications for the Polish-Russian relationship, including the potential to foster reconciliation, and thus on international relations more generally. The Katyń Massacre is an important example of how memory politics are often times multi-layered and how memory affects foreign policy and vice versa.

\section{BACKGROUND AND THE "KATYŃ LIE"}

The history of the Katyń Forest Massacre and its aftermath is long and has been frequently contested between Polish and Russian scholars, although in the past decade important steps toward reconciliation were tentatively made as more cooperation from the Russian Federation to resolve the issue became evident. However, the facts remain that slightly less than 22,000 Polish officers were murdered in 1940 in Kozelsk, Starobelsk, and Ostashkov prisoner camps by the Soviet secret police, the NKVD, and the execution sights were in several locations such as Katyń, Kharkiv, Mednoe, and Bikivnia. The Germans found the Katyń mass gravesite near Smolensk perhaps as early as 1941 but released their findings to the world only in 1943 in an effort to disrupt the grand wartime alliance against them. Before the discovery of the Polish officers' corpses at Katyń, however, is where the controversy begins. 
After the invasion of Poland by the Germans in 1939 the Soviets sent the Red Army west in order to "save" their Belorussian and Ukrainian brethren. ${ }^{31}$ The Polish government no longer existed in Warsaw and thus the Polish state was declared to be "nonoperational." As the Soviets took control of Polish territory many Polish officials and soldiers were shot on the spot and many others were taken into captivity because these Poles were deemed to be "anti-Soviet" or counter-revolutionary by the Soviet communist regime. ${ }^{32}$ Around 230,000240,000 soldiers of the Polish military were captured and put into prisoner-of-war camps and logistically this eventually became too much for the Soviet Union to handle. ${ }^{33}$ On 5 March 1940 the Politburo decision was made to shoot the Polish Army Officers in the Ostashkov, Starobelsk, and Kozelsk camps. Most of the prisoners in the Ostashkov camp were killed in Kalinin in batches of 250 inside a building, while some prisoners survived. ${ }^{34}$ The prisoners in the Starobelsk were killed in Kharkov mostly inside a building and later their corpses placed into a wooded area. ${ }^{35}$ The prisoners of the Kozelsk camp's fate are less known as there is yet any testimony that has surfaced, but it is evident from the corpses, a dairy preceding the killing, and one survivor pulled away at the train station, Stansław

\footnotetext{
31 The word "save" is in quotation marks because of the Soviet Union's prior agreement with the Germans through the Molotov-Ribbentrop Pact signed 23 August 1939. This pact essentially divided the territories of Eastern Europe, and Poland into two spheres of influence between the Nazis and the Soviets, which enabled the later invasions. The Soviets were not just going into eastern Poland to save their brethren but to take Polish territory. Anna Cienciala et al., Katyn: A Crime Without Punishment (Yale University Press, 2008), 2.

32 Ibid, 24.

${ }^{33}$ Ibid, 26.

${ }^{34}$ Ibid, 121-122.

${ }^{35}$ Ibid, 126.
} 
Swianiewicz at Gnezdovo Station, that the officers were taken by bus and killed in the Katyń forest. ${ }^{36}$

On the home front Polish families were assured by Stalin numerous times that their husbands or fathers would return home after some time working in Siberia helping the Red Army in mines or on highways. When the families that were not already deported began to question why their husbands and fathers remained missing Stalin blamed lower-level officials who were supposed to "release the soldiers to return home." Finally, unable to continue biding for time and unable to continue lying to the Polish families any longer, Stalin further exiled any remaining families of the "missing" soldiers in order to silence suspicions. ${ }^{37}$ In fact, just a month before the Politburo decision to eliminate the officers there was a second wave of deportations of soldier's families from Western Ukraine and Western Belorussia to the east, many to collective farms in Kazakhstan. ${ }^{38}$ These deportations and the Politburo decision were made in order to secure the Soviet position in eastern Poland, which had been incorporated into the western Belarussian and Ukrainian Soviet Republics.

In 1941 Polish workers employed by the Germans in the Todt labor organization learned from locals near Smolensk of the shootings of Polish officers in the forest. These Polish workers dug in the area and found human bones and military insignia but these findings however, did not attract German

\footnotetext{
36 Ibid, 130.

${ }^{37}$ George Sanford, “The Katyn Massacre and Polish-Soviet Relations, 1941-43," Journal of Contemporary History 41 (2006): 95.

${ }^{38}$ Cienciala, 121.
} 
attention until there were wolf tracks in the area in early $1943 .{ }^{39}$ This is when the Germans drew attention to the remains and word was sent to the Army Group Center (AGC) command, one of the Germany army groups set up on the Eastern front. ${ }^{40}$ When the Germans released their findings of the Katyń gravesite in early 1943 Joseph Goebbels, the head of Nazi propaganda, used Katyń as antiBolshevik propaganda in order to try and turn the western allies against the Soviet Union as well as to create support for Germany in Nazi-occupied territories, including Poland. The Germans even agreed to an International Red Cross investigation of the site. However, the Soviet Union and even Churchill agreed that this investigation would be flawed because it was ultimately under Nazi Germany's influence, although Churchill thought that the German findings were "probably true". ${ }^{41}$ During and after the war the Soviets denied responsibility for the Katyń Massacre. calling it a "Nazi atrocity", which soon became known by Poles as the "Katyń Lie", one which some Russians still deem as factual. ${ }^{42}$ Stalin played into the "Katyń Lie" during World War II and created small Polish army factions with names like "The Avengers of Katyn'", all under the supervision of the Red Army. ${ }^{43}$ After World War II with Poland now under the domination of the Soviet Union, the Katyń Forest Massacre's memory was suppressed in Poland. Poles were unable to write or speak about Katyń as anything other than a Nazi

\footnotetext{
39 Ibid, 215.

40 Ibid, 215.

${ }^{41}$ Gorska, 146.

42 In short "The Katyń Lie" is the claim that the Nazis committed the murders of the Polish officers at Katyń; Alexander Etkind et al., Remembering Katyń (Cambridge: Polity Press, 2012), 5.

${ }^{43}$ Sanford, 98.
} 
crime and monuments to the Katyń Massacre victims such as Melak's cross erected by the Polish communist regime in 1985 in Powązki, a large war cemetery in Warsaw, were few and closely monitored by the Soviet Union. ${ }^{44}$

Historically the most important and openly active tenet for Poles during and after World War II in the contentious relationship with Russia was fighting the "Katyń Lie." The Katyń Lie began in October 1943 when the NKVD and the People's Commissariat for State Security (NKGB) began creating a false picture of what took place in the forest. ${ }^{45}$ The NKVD and the NKGB secured the site and placed documents, such as papers dated after Soviet withdrawal from Smolensk from those who did not die at Katyń, on the corpses to show that the Polish officers were still alive under the Soviets. ${ }^{46}$ In January 1944 a special commission was created, the Burdenko Commission, in order to further perpetuate and strengthen the Katyń Lie by conducting an "investigation" and even collecting false testimonies. ${ }^{47}$

Since the revelation of the Katyń gravesite in 1943 Polish émigrés in the West fought the Katyń Lie and continued resistance to it during the communist era when public discourse in Poland was heavily censored and the Katyń Lie remained the official narrative. The émigrés published papers and books, which

\footnotetext{
${ }^{44}$ Etkind et al., 21.

${ }^{45}$ Witold Wasilewski, "The Birth and Persistence of the Katyn Lie," Case Western Reserve Journal of International Law Vol. 45 (2013), 678.

${ }^{46}$ Other documents were also produced, including the findings of the Krugłow-Merkulov team which were contained in a signeddocument entitled Information on the Results of a Preliminary Investigation into the So-Called Katyn Matter that said the Polish prisoners of war under the Soviets were working on a road until the Soviet-German war and that the Germans captured and killed the Polish prisoners and blamed the killings on the Soviets in the autumn of 1941. Ibid, 678-679.

${ }^{47}$ Ibid, 682.
} 
were smuggled to Poland and worked on raising awareness about the Katyń Forest Massacre in the West. This included Polish-American resistance fighter Janusz Kazimierz Zawodny's book Death in the Forest (1972). The Katyń Massacre continued to be presented in the Soviet Union until the Gorbachev era as a Nazi crime. The long and continuous fight for the truth against the Katyń Lie would come to play a large part in the future contentious relationship between Poland and the Russian Federation, the successor to the former Soviet Union, primarily because it has played such a vital role in Polish memory politics.

\section{CONTENTION AND NEED FOR AN APOLOGY}

Along with fighting the Katyń Lie, the larger Polish experience with Soviet domination has its own long history and its impact has penetrated deep into Polish identity. The Katyń Massacre not only represents the actual massacre, but also represents the struggle of Polish society against a communist regime imposed by the Soviet Union at the end of the Second World War. Not only was the Soviet Union the perpetrator that committed the crime and tried to suppress the memory of the massacre, it also dominated postwar Poland. ${ }^{48}$ The Katyn Forest Massacre symbolizes more than just a crime but a site of memory. No living Pole was a witness to the killings, thus the mentality is that because "no one could remember the killings so everyone should remember them" and this connects and unites the Polish people through connective memory bonding. ${ }^{49}$ The Warsaw Uprising is another important contributor to Polish identity, but this event plays into the image of the fearless Pole who would die with honor rather

\footnotetext{
${ }^{48}$ Sanford, 95-96.

${ }^{49}$ Ėtkind et al., 14.
} 
than that of the victimization and grief which the Katyn Massacre symbolizes. ${ }^{50}$ The Polish people were unable to fully grieve the deaths of these victims as citizens in a satellite state of the Soviet Union and this only added to the need to remember the victims.

The years 1988-1992 however, marked a period of development in the truth about the Katyń Massacre and even steps toward Polish-Russian reconciliation. In 1986 after the meltdown of the Chernobyl nuclear reactor in 1986, President Mikhail Gorbachev announced his glasnost policy, which promoted public discussion of Stalinist crimes. Immediately following this announcement pressure was put on the Soviet Union by Polish historians and the Polish media to uncover the truth of the massacre which led to a monument in Katyń of both Polish and Soviet victims to Nazi crimes, but no archival documents were released at the time. Further pressure was put on Gorbachev and the Soviet Union in 1989 when Solidarity members defeated the PZPR candidates in semi-free elections in June, marking the beginning of the end of communism in Poland.$^{51}$ Finally, in 1990 after Polish President Jaruzelski said he would not visit Moscow unless the truth about Katyń was admitted and an interview was conducted by Moskovskie Novosti entitled "The Katyń Tragedy" with one of the three Russian historians allowed to view formally closed archives,

\footnotetext{
${ }^{50}$ The Warsaw Uprising was a massive act of resistance to the Nazis by the Polish Home Army in 1944. This memory has always been widely accepted even by the Soviets, although evident is some distortion about the liberation by the Red Army, and continues to be a source of national pride today. While many died, The Warsaw Uprising is a proud symbol of martyrdom in Polish collective memory. Janusz Zawodny, Nothing but Honour: The Story of the Warsaw Uprising 1944 (Stanford: Hoover Institution Press, 1978), 22.

${ }^{51}$ Cienciala, 248.
} 
Gorbachev handed Jaruzelski the NKVD dispatch lists for the prisoners that were executed in 1940, but this list however, did not include all of the documents related to the Katyń massacre ${ }^{52}$ The documents with the Politburo decision were given in 1992 to President Wałęsa under Yeltsin's name which marked a huge step in Polish-Russian reconciliation. ${ }^{53}$

In 1994 German President Roman Herzog issued an apology for the crimes committed in Poland by the Nazis during World War II causing an outcry for a Katyń apology. An apology as well as compensation for Katyń was repeatedly called for in subsequent years, but there has yet to be an adequate apology that all Polish political parties deem acceptable. Accepting full responsibility for the Katyń Forest Massacre and offering compensation under Polish law or a third party court could finally appease all political factions in Poland and enable Poland to move on and begin to fully reconcile with Russia over the issue of Katyń. ${ }^{54}$ The Russian Federation did take steps to offer cemeteries to all victims in Katyń, Mednoe, and Kharkov and it opened these cemeteries in 2000 , which was seen as another positive step in Polish-Russian relations. ${ }^{55}$ However, in truth a continued lack of a direct apology, as well as avoidance of an apology by simply blaming Stalinism, along with Russian failure to release all the archival documents related to the massacre has only fueled further troubles in the relationship between the Russian Federation and Poland

\footnotetext{
52 Ibid, 253.

53 Ibid, 256.

54 Ibid, 236-237.

${ }^{55}$ Cienciala, 258.
} 
and allowed right-wing parties in Poland to utilize Katyń for their own political gain. ${ }^{56}$

The need for a more precise apology exemplifies the need for recognition of the wrongs of the past but also the need to further fill the "blank spots," or missing pieces of the past, between the Soviet Union and Poland. In 1989, as mentioned previously, under Gorbachev's glasnost all Polish politicians wanted these blank spots to be filled, but as long as the Soviet Union continued to exist and Poland formally remained a member of the Warsaw Pact, these issues were not pushed as strongly as they would be in later years. ${ }^{57}$ The Russian Federation at first did agree to investigate the massacre and to award compensation, but under Russian law. This Russian investigation was seen as unfair by the PiSdominated Polish government which came to power in 2005 and launched its own investigation. In the meantime, back in 2004, Poland put its case before the European Court of Human Rights. ${ }^{58}$ Polish officials declined Russia's symbolic gesture of compensation in 2008 in exchange for dropping all Katyń charges after the court accepted the first case, causing further strain. ${ }^{59}$

Opportunities for a new period of reconciliation, however, had already begun to appear in 2007 following the defeat of PiS in parliamentary elections and the formation of a new coalition government headed by Civic Platform's Donald Tusk. Renewed Polish-Russian negotiations over Katyń culminated on 7

\footnotetext{
56 "Russian Files Show Stalin Ordered Massacre of 20,000 Poles in 1940," The New York Times, October 151992.

${ }^{57}$ Gorska, 147.

${ }^{58}$ Ibid, 160.

${ }^{59}$ Ibid, 173.
} 
April 2010 near the anniversary of the massacre, but this time beside Polish Prime Minister Donald Tusk, the Prime Minister of the Russian Federation, Vladimir Putin, became the first leader from the Russian Federation who officially commemorated the victims of the Katyń Forest Massacre. ${ }^{60}$ The commemoration included priests, wreaths, candles, and a symbolic cemetery for the victims of the NKVD. ${ }^{61}$ Putin in his commemoration gave a speech admitting the Soviet crimes and calling for "peace and prosperity" for future generations of Poles and Russians as partners in the international order. ${ }^{62}$ Putin's speech and commemoration was widely well received in Poland and was even deemed the "finale of the Katyń Lie." ${ }^{63}$ This gesture to Polish memory by Russia was seen as a step toward ending the Polish-Russian contentious relationship over the issue. This step was treated as a new opening in Polish-Russian relations because of Putin's presence, his commemoration of the dead, and his speech. Reconciliation seemed plausible after Putin's actions and it appeared as if a new era of relations between the Russian Federation and Poland could begin. ${ }^{64}$

There was of course some skepticism among the Poles; a Polish diplomat was cited as believing that the speech was all a political scheme and that all Katyń related documents still needed to be released. ${ }^{65}$ Some Poles from PiS still criticized the Russian Federation for what they considered an inadequate

\footnotetext{
60 "Putin Marks Soviet Massacre of Polish Officers," The New York Times, April 7, 2010.

61 "Polska i Rosja bliżej pojednania," Gazeta Wyborcza, April 8, 2010.

62 "Władimir Putin: Nie mamy prawa zostawiać następnym pokoleniom nieufność i wrogość," Gazeta Wyborcza, April 7, 2010.

63"Wysoko oceniam przemówienie Putina," Gazeta Wyborcza, April 8, 2010.

64 "Niech Katyń nas pojedna," Gazeta Wyborcza, April 8, 2010.

65 "Polska i Rosja bliżej pojednania," Gazeta Wyborcza, April 8, 2010.
} 
apology that they had also hoped for during the commemoration. On the other side Russian communists criticized Putin for giving any kind of an apology at all, and adhered to the myth of "German responsibility for the shootings of Polish soldiers." ${ }^{\text {"6 }}$ An apology or a "perfect apology" for historical injustices often times can decompress a contentious relationship by admitting to an injustice and apologizing so that the victim nation can grieve and move forward and this was the hope of Polish-Russian relations. ${ }^{67}$

All countries face psychological difficultly when addressing the wrongs or dark aspects of their pasts, and this too is the same with the Russian Federation. This difficulty is seen as one of the reasons why many Russians blame the Stalinist era because of their positive memory of the Great Fatherland War and the power that the Soviet Union had at this time. There are several different narratives in Russia when addressing Katyń; some believe that the published documents are false and anti-Russian lies, many believe that the names of the victims on the NKVD list given to Jaruzelski by Gorbachev do not match the German list, and others condemn Poland for carrying out a massacre of Russians in the Polish-Soviet war in $1919-1920$ as well as Soviet prisoners dying of disease and hunger after the Polish-Soviet war in prisoner of war camps, equating this massacre with the Katyń massacre, although the Russians in this

\footnotetext{
66 "Putin Marks Soviet Massacre of Polish Officers," The New York Times, April 7, 2010.

${ }^{67}$ Craig W. Blatz et al., "Government Apologies for Historical Injustices." Political Psychology. Vol. 30, No. 2, (2009), 219-221.
} 
case did not die by order of the Polish political and military leadership but under other, local circumstances. ${ }^{68}$ For Poles, this is the key difference.

\section{KATYŃ IN FILM}

In 2007 Andrej Wajda's award winning film Katyń ${ }^{69}$ portrayed the effects of the Katyń Forest Massacre on Polish society in Nazi-occupied and post-war Poland. Wajda uses a variety of fictional characters and storylines in order to show how widely the Katyń Massacre affected Polish society. However, while Katyń serves as a tool for expression of memory it is important to look at other sources and consider how film more generally has played a role itself in the construction of collective memory and in turn memory politics.

Film, like a monument, is able to serve as a mode for expressing grief or representation of an event, but more so than a monument film can alter one's perception of the past and historical memory through visual interpretation and emotions. Just like oral history, film can add its own narrative into the audience's memory, therefore altering or completely changing the audience member's original thought or memory of the event. This medium can "restage the past and exploit it" or "reconstruct and shape the past" according to the agenda of the person or persons involved with the film. ${ }^{70}$ Feelings are often "exploited" or fueled with film through emotional scenes and images that place the viewer at the scene of the action.

\footnotetext{
68 Ibid, 263.

${ }^{69}$ Based on Andrzej Mularczyk's screenplay Post Mortem: The Story of Katyn. Katyń directed by Andrej Wajda (Poland: ITI Cinema, 2007).

${ }^{70}$ Aleida Assman, 54.
} 
Representing memory through film is in the hands of the director and his or her cinematic choices in telling a story. The director of Katyń, Andrej Wajda, has a personal connection to the Katyń Massacre as his father was one of the victims and therefore Wajda himself has his own narrative and motive in making the film. This is important to keep in mind when viewing Katyń. Katyń uses some evidence to tell parts of the story, integrating older film and recordings of the Katyń gravesite into the story in order to give the film and its narrative a feeling of authenticity. However, the representation of characters, music, and killing scenes in Katyń are all sequences used to stir up emotion in the audience as well as to portray aspects of the Katyń Forest Massacre that have not been documented or for which the documents have not been released. The only available non-Soviet firsthand personal account of the Katyń Forest Massacre is that of Stanisław Swianiewicz who was pulled away from the Gnezdovo train station outside of the forest where the massacre took place and therefore, the final interrogation and killing scenes are Wajda's interpretations of what took place during the massacre. ${ }^{71}$ Katyń is not based on a firsthand account nor is the film nonfiction, yet it has played a major role in memory politics through its public reception. Although Wajda has had to invent some scenes his goal was not to target Russians or even Soviet citizens but to criticize the Stalinist regime, reveal the truth, and relay the importance of this tragedy to the world. ${ }^{72}$

Katyń has had a strong influence on Polish society and entered the sphere of memory politics between Poland and Russia in 2007 when the film débuted

\footnotetext{
${ }^{71}$ Ėtkind et al., 14.

72“"Andrzej Wajda pokazał “Katyń” w Moskwie," Gazeta Wyborcza, March 19, 2008.
} 
and 2008 when the film was screened for Russian audiences. The day after the premier of the film Wajda met with Russian journalists and guests to screen the film again in order to gauge how a Russian audience would perceive the film. In October 2007 the film was privately screened in the Polish Embassy of Moscow to Russian historians, politicians, and even Putin's advisor Sergei Yastrzhembsky. ${ }^{73}$ Katyń continued to grow in popularity internationally and continued gaining interest among Russians even though promotion of the film in Russia was not highly visible at first. ${ }^{74}$ Interest of the film among Russians was evident when there was an over-packed screening of the film in March 2008 in Moscow during a festival of Polish culture.$^{75}$ The film was also screened several months later in St. Petersburg and Smolensk to commemorate the victims of the massacre on the anniversary of the massacre ${ }^{76}$ Although there was some concern on how Russian audiences would perceive Katyń the film was widely embraced. This film emotionally impacted the audiences; some with tears in their eyes and some even offering apologies. ${ }^{77}$

Katyń became widely available to the Russian public on the second of April when the film was released on the Russian culture channel coinciding with the upcoming commemoration of Katyń with Putin and Tusk. ${ }^{78}$ The film received

\footnotetext{
73 "W Sprawie Promocji Filmu "Katyń" w reżyserii Andrzeja Wajdy na terenie Rosji," Odpowiedź ministra kultury I dziedzictwa narodowego, May 14, 2008.

${ }^{74}$ Ibid.

75 “'Катынь' Вайды будет демонстрироваться в России," ИноСМИ, January 25, 2008., and "Wzruszenie I cisza na "Katyniu" w Moskwie," Wprost, March 18, 2008.

76 "W Sprawie Promocji Filmu "Katyń" w reżyserii Andrzeja Wajdy na terenie Rosji”

77 "Wzruszenie I cisza na "Katyniu" w Moskwie"

78 “Россия увидит "Катынь"," svoboda, April 2, 2010.
} 
high ratings with two and a half times more viewers of the program than the channel's average and overall well received by this audience. ${ }^{79}$ Although the film was eventually shown in Russia, Katyń was criticized by some Russians, including Russian Communists, for its dramatized representation of Soviet characters and "inaccuracies." ${ }^{80}$ The film thus served as a bone of contention for some in Russia but overall was well received and even brought about some reconciliation. Thus it has played a major role in memory politics between the two states. Because of the international recognition it received and the quality of the film. Katyń served as the beginning of a conversation of the Katyń Forest Massacre between Poland and the Russian Federation besides serving as an artistic medium to tell an important story about the past.

\section{The 2010 PLANE CRASH}

In addition to the massacre in the Katyń Forest, Katyń became further layered with grief in 2010 when a plane crashed in the area of Katyń near Smolensk killing Poland's President, Lech Kaczyński, and many other top officials on their way to commemorate the victims of the Katyń Forest Massacre, just three days after Putin's commemoration with Prime Minister Donald Tusk that was seen as a positive step in Polish-Russian relations. ${ }^{81}$ The plane crash rehashed the emotions that came from the root of the problem, the Katyn

\footnotetext{
79 “"Катынь" Анджея Вайды в государственном телеэфире,” gazeta kommersant, April 7, 2010., and "Приоткроет ли демонстрация фрильма Анджея Вайды "Катынь" завесу молчания над катынской трагедией?," Svoboda, April 3, 2010.

80 “Фильм «Катынь»: Взрыв очередной антисоветской хлопушки," kprf.ru, April 9 , 2010.
}

81 "Polish President Dies in Jet Crash in Russia," New York Times, April 10, 2010. 
Massacre. This plane crash and death of many government officials added to the sense of victimization among many Poles and again connected their identity with a tragic event.

Russia's response following the plane crash was important to RussianPolish relations, especially since Putin had just commemorated the Katyń Massacre several days before and his actions had been so well received in Poland. Russian President Dmitri Medvedev announced, "Russia shares the grief and mourning of Poland" and declared a day of national mourning in Russia. ${ }^{82}$ This gesture of condolence from Russia was taken as a sign of good faith and many Poles stricken with grief felt that their long contentious relationship with Russia over Katyń could finally begin to heal through Russia's attitude toward this new tragic event. That weekend in April from Putin's speech and commemoration as well as Russia's act of good faith following the tragedy of the plane crash highlighted the opportunity for on-going reconciliation between the two states and a new era in their relations.

This brief moment of seemingly good relations and hope of finally healing a long contentious relationship hit a bump when many right-wing Poles began to question the plane crash. Sensitive information such as diplomatic codes, documents, NATO information, and telephone correspondence recovered by Russia at the site of the crash also stirred concern in the international community. Since Russia never issued an apology for the Katyń Massacre sufficient enough to appease rightist groups in Poland, the crash fueled their

82 "Can Russia and Poland Forget Centuries of Animosity in a Single Weekend?," Foreign Policy, April 16, 2010. 
suspicions of the Russian Federation and caused a stir in Polish domestic politics. One target of rightist outrage was a memorial in a Soviet cemetery in Warsaw where 20,000 soldiers are buried, which was vandalized in November. The message left by the vandals read, "Tusk, we want the truth (Tusk chcemy prawdy)," referring to the plane crash in Smolensk.

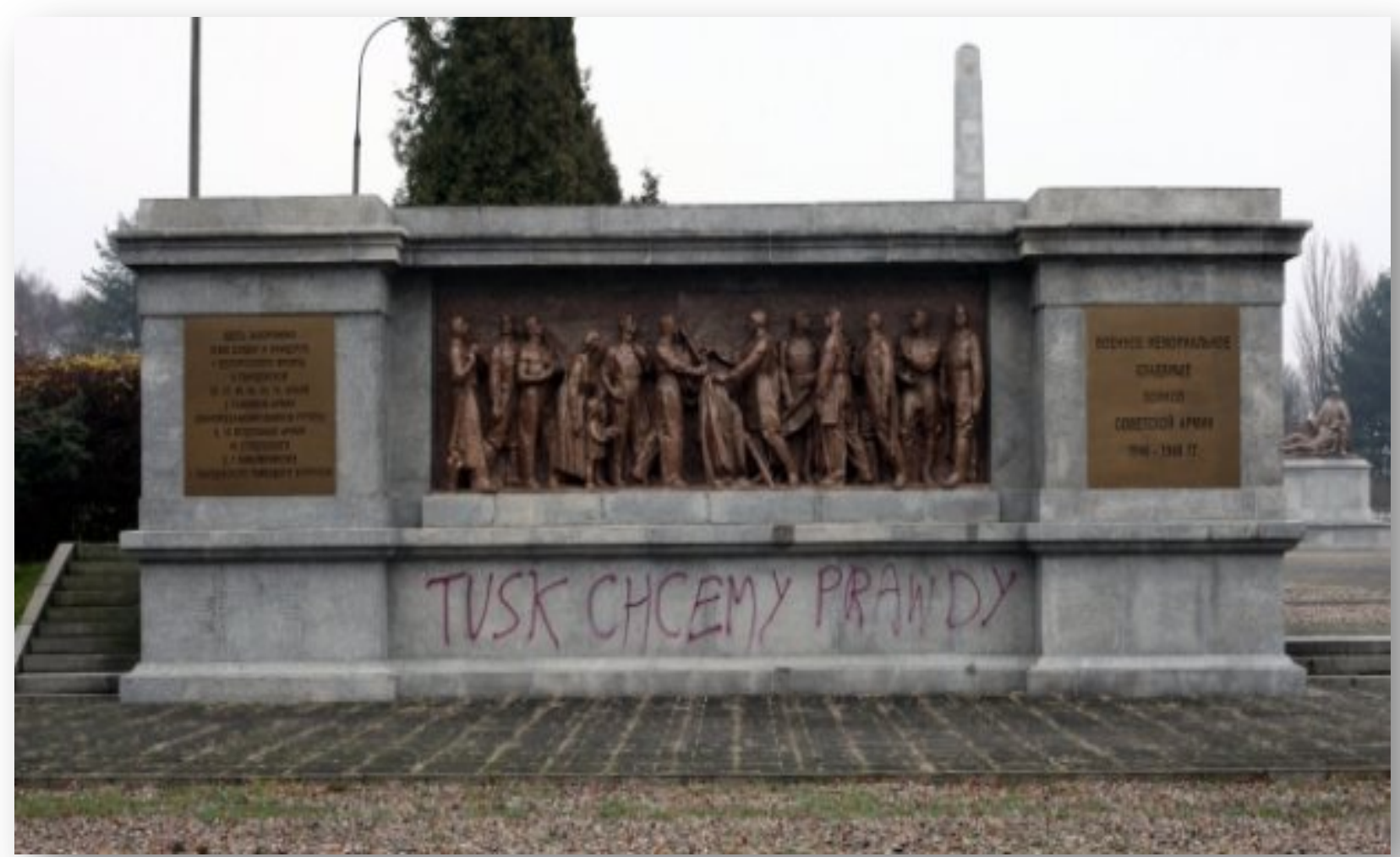

Figure 1: "Tusk Chcemy Prawdy",83

In 2011 a Russian investigation into the crash put the crew at fault for landing in bad weather when advised otherwise by Russian air traffic controllers. ${ }^{84}$ This conclusion did not bode well with the Polish right led by

\footnotetext{
83 "Zdewastowany cmentarz: "Tusk chcemy prawdy," Gazeta Wyborcza, November 17, 2010.
} 
Jaroław Kaczynski, President Lech Kaczyński’s twin brother Jarosław Kaczyński who had founded PiS and now became a candidate in presidential elections to succeed his deceased brother. The PiS leader claimed that, "Anyone who knows Russia could have guessed that this is what the report would look like," that the Tusk government was "too soft" on Russia, and that Russian air controllers were "misguiding Polish pilots and giving them false information." ${ }^{85}$ Rightists named the Russian report of the plane crash the "Smolensk Lie," playing on collective memory of the previous "Katyń Lie."

News articles with titles like, "Did Putin Blow Up the Whole Polish Government in 2010? A Second Look" and "Polish Plane Crash Was Assassination, His Brother Says," also appeared in the international media, including major outlets in the U.S. and U.K., in the years following the crash. ${ }^{86}$ These titles emphasize the distrust and suspicions of conspiracy that the rightist groups were trying to exude toward Russia in order to gain advantage within Polish domestic politics. Jarosław Kaczyński clearly exploited this tragic event in order to promote himself and a rightist agenda in the ensuing presidential and parliamentary elections.

Kaczyński's party lost those elections, but in 2015 in the midst of the most recent presidential election campaign in Poland the Russian Federation refused

84 "Crew Error Led to Polish Plane Crash, Russians Conclude," CNN, January 12, 2011.

${ }^{85}$ Crew Error Led to Polish Plane Crash, Russians Conclude," CNN, January 12, 2011.

,"Did Tusk Go Soft on Russia?," The Economist, January 13, 2011. And "Poland's Kaczynski Slams Russian Crash Report," Euronews, January 12, 2011.

86 "Did Putin Blow Up the Whole Polish Government in 2010? A Second Look," The Daily Beast, November 4, 2014. and "Polish Plane Crash Was Assassination, His Brother Says," ABC News, March 29, 2012. 
to return the wreckage of the plane. ${ }^{87}$ Russia claimed that Poland's inaction to provide legal aid to the final Russian investigation had left the case open and thus the evidence could not to be returned. ${ }^{88}$ Although some worried that PiS would again use the Smolensk plane crash for its electoral political purposes, the major focus of the strategy of its ultimately successful 2015 presidential candidate, Andrzej Duda, was to emphasize traditional national values as a solution to the country's social and economic problems and Euroskepticism in relation to Brussels.

Nonetheless, the plane crash in 2010 had layered the grievous memory of the Katyń Massacre with new memory and although it had officially been declared an accident due to weather conditions Russia still received the blame in the minds of right-wing Poles. The first response to the crash by Russia was seen as a courteous gesture possible of healing animosity, but in the end the plane crash only deepened aspects of contention between Poland and the Russian Federation as it became entangled in Poland's domestic political conflicts. Although the myth of Russia causing the crash of the plane as part of a conspiracy to eliminate Lech Kaczyński from the Polish political scene has been debunked in the minds of most the question of why the wreckage of the plane has not been returned to Poland by Russia remains a sore point in their relations.

\section{CONCLUSIONS}

\footnotetext{
87 "Grounded: Poland-Russia Relations," Carnegie Europe, April 13, 2015.

88 "Russia Unable to Close Smolensk Crash Investigation due to Polish Inaction," Radio Poland, April 9, 2015.
} 
Since the end of the Soviet era, the Russian Federation and Poland have both signs of contention as well as cooperation dealing with the Katyń massacre. Since Poland's independence from the Soviet Union and the era of glasnost policy under Gorbachev the dialogue between them over Katyń continued to change, debunking years of myths and revealing much of the truth surrounding the massacre. The Katyń Forest Massacre will always remain a dark page in Polish history and an event to memorialize and remember. With the tragic plane crash in 2010 Katyń again become layered with grief, but between 2007 and 2010 signs of healing between Poland and the Russian Federation were clearly visible through the latter's willingness to commemorate the victims of the massacre, its expression of condolences at the time of the presidential plane crash, and the favorable reception Russian officials and audiences accorded to Wajda's Katyń.

There are those in both the Russian Federation and Poland who still contest one another over the massacre or the portrayal of the massacre. PiS in Poland, with its stance of "no forgiveness" and even sponsoring rightist monuments related to its version of the plane crash, continue to make reconciliation difficult in Poland while those in Russia, like communist party, deny Katyń or continue to believe in the Katyń Lie, which has made reconciliation difficult in Russia. These domestic contentions thus play a role in international memory politics. Luckily this is not the majority as seen through Polish reactions to Putin's commemoration and speech, Russian reception of Wajda's Katyń, and Russia's official reaction to the 2010 plane crash. 
Poland has come to play a major role in international politics and has many achievements to build a strong and proud Polish identity. Sadly, the Katyń Massacre, however, will remain part of the Polish identity through its contribution to the connective bonding memory of victimization. As seen in recent years these contested memories can be reconciled through sincere mutual commemoration. Hopefully as time progresses Poland can note many new achievements as part of a proud identity and look back at the Katyń Massacre as a historical memory rather than an open wound. The Katyń Forest Massacre is an important example of memory politics because of the role its durable memory has played in relations between the Russian Federation and Poland as well as in domestic politics that can drive new narratives, like the Smolensk Lie. The Katyń Forest Massacre is an example of how memory affects international relations as well as how often memory is shaped by international relations. Memory politics will continue to be emotional and passionate when speaking about a traumatic event such as the Katyń Massacre and animosity will certainly be extended to those who try to deny Soviet responsibility for the Katyń Massacre or those who consciously attempt to link it to the 2010 plane crash at Smolensk. 


\section{Chapter 3: Soviet Monuments and Memorials in Poland}

The troubled relationship between Poland and the Russian Federation expressed in and shaped by memory politics not only lies with events or more specifically the event of the Katyń Forest Massacre, but also by the Soviet memory represented in public space such as monuments constructed in Poland during the communist era and the conflict of narratives surrounding them. Twenty-six years after the fall of communism and the reestablishment of an independent Poland, the presence of Soviet monuments in Poland is still a controversial topic in contemporary society. Poland is faced with internal and external pressures about what to do with these monuments, many of which have stood in place for a generation or more. Not just exclusive to metropolitan cities the Soviet monuments play a major role in memory politics within Poland and often create contention with the Russian Federation, as in the case of the Brotherhood in Arms monument in Warsaw. The Russian Federation has inherited the Soviet past and therefore has a strong connection with the many monuments dedicated to the Red Army. Thus any initiative to remove these monuments can be deemed as offensive or an attack on the Russian Federation if not handled diplomatically.

\section{MONUMENTS, MEMORIALS, AND MEMORY}

When a monument is erected there is typically a given narrative and a political or social reason behind the monument. Monuments are constructed to serve as what Jan Assman calls "memory aids" or "lieux de mémoire", that is as 
tools where "national memory is concentrated" and where the collective memories become a physical symbol of identity. ${ }^{89}$ The narrative or national memory intended, however, is not always the narrative that the monument creates. Many factors such as location, plaques, architects and designers, money for the monument, the organization or regime that sponsored the monument, and the monument itself can create different narratives than the one intended or can become interpreted differently by the society. What Assman did not take into account is when this "memory aid" becomes more of a "memory scar" for a large part of society, representing something completely different than what the national memory is supposed to evoke. Monuments are a physical representation of an event and typically have a strong emotional meaning to the society. Identity plays a large role in monuments as many monuments are either intended to be national symbols or have something to commemorate for the nation. Monuments typically try to evoke a national or a connective bonding memory, which can unite a community, multiple communities, or even nations depending on the event and how the monument is presented.

Contention and disputes are common with monuments in memory politics because of the "other" narrative a monument creates. Monuments can become layered with memory when new narratives are added. For example, when a politician gives a political speech in front of a monument the politician is trying to evoke the original narrative of the monument to his or her advantage, but depending on the speech can also add a new narrative to the monument. In

\footnotetext{
89 Jan Assman, 8.
} 
many instances monuments become meeting places for important anniversaries or meeting places for supporters of political revolution seeking to use the monuments' symbolic meaning. Many monuments are memorials dedicated to fallen soldiers or important political figures and, since they can be subjected to a layering of memories as well, are typically more emotionally charged. The memory layers of a monument can continue to change over time with different generations. The symbolic meaning of a monument can continue to become layered as new narratives are added to the original "intended" narrative.

In the case of Central and Eastern Europe the monuments created by the Soviet Union and its dependent communist regimes to represent either liberation of a state or as commemoration to the Red Army have come to represent a new narrative after the fall of communism in 1989 and after the break-up of the Soviet Union in 1991. The Soviet monuments after Poland's independence and the collapse of the Soviet Union represent for many a physical symbol and reminder of former domination and a painful past while to others the monument continues to serve as a reminder of its original narrative. These two narratives are highly emotional and cause conflict within the former Soviet or communist state and with the present-day Russian Federation. While there are typically more layers than those frame by two bipolar narratives, the two aforementioned narratives encompass most groups in Poland, including those who may not agree with the monuments meaning but want to keep it as a representation of past reality. An example of this "battle of narratives" is the Bronze Soldier Statue in Tallinn, Estonia where ethnic Russians understood the monument according to its 
original narrative created by the Soviets and ethnic Estonians understood the monument as a symbol of occupation. ${ }^{90}$

International politics alongside memory politics can come into play with monuments when another state is involved. Monuments can be a symbol of the connected past of two states or a symbol of their strong alliance. When these monuments are changed, moved, or destroyed, conflict can arise between these states. Therefore memory can play a large role in international relations and states act cautiously if implementing change toward a monument involving more than just one nation's memory.

\section{BACKGROUND AND SOVIET MONUMENTS AFTER 1989}

In Poland after 1989 there have been two major narratives when dealing with Soviet monuments and contention between the two narrative groups. The original narrative of these monuments, set by the Soviet Union, is either of the liberation of Poland from the Nazis or the commemoration of lost Red Army soldiers fighting the Nazis. In sum, these monuments glorify the Soviet Union. These monuments, however, carry a layered memory, or narrative, of almost five decades of communist rule or influence by the Soviet Union. These monuments to many Poles are a physical reminder of Soviet domination. However, some Poles, mainly the older generation who have lived much of their life in this era, former communists, and those who do not want conflict, view these monuments

\footnotetext{
90 The Bronze Soldier statue was put in place in Tallinn by the Soviet Union as a monument for the liberation of Tallinn from the Nazis. This monument became highly controversial between ethnic Estonians and ethnic Russians in Estonia in 2007 when the monument was moved from its original position in Tallinn's old city to a gravesite in the outskirts of Tallinn. Siobhan Kattago,. "War Memorials and the Politics of Memory: the Soviet War Memorial in Tallinn" Constellations Vol. 16, No. 1 (2009).
} 
as simply part of Poland's past, even though it was under Soviet influence. With these two narratives there is contention within Poland and with the contemporary Russian Federation and the monuments often times become an outlet for this conflict. The most difficult aspect in resolving these conflicted narratives is what to do with the monuments in order to appease domestic public opinion but not cause tensions with a Russian Federation that continues to pose a security threat. In the past and in other Central and Eastern European countries governments have destroyed monuments, moved monuments to cemeteries, moved monuments to museums, and altered monuments. Each decision on how to treat a Soviet monument is highly political and can cause domestic tensions leading to violence, like the riots in Estonia over the Bronze soldier, as well as international political repercussions.

Since Poland became independent again in 1989 there has been constant conflict on how to handle Soviet monuments. During the 1990's it was not in newly independent Poland's best interest to start a conflict with the Russian Federation, and local governments were left in charge of deciding the fate of their monuments, which happened to be the case of most monuments. ${ }^{91}$ This aversion to conflict mixed with Poland's desire to draw a "thick line", also referred to as "collective amnesia", in order to not focus on the communist past, or forget that past and move forward, certainly had implications on the physical representations of the recent past, namely the monuments. Many monuments were either taken down and replaced with new monuments to represent Poland

\footnotetext{
${ }^{91}$ Ewa Ochman, Post Communist Poland-Contested Pasts and Future Identities (New York: Routledge, 2013), 15.
} 
or modified to reflect Poland, such as the exchanging of Soviet symbols with Polish symbols. Some monuments were further explained with informative plaques like the Monument of Gratitude to the Red Army in Legnica that depicts a Soviet and Polish Soldier holding a Polish child.

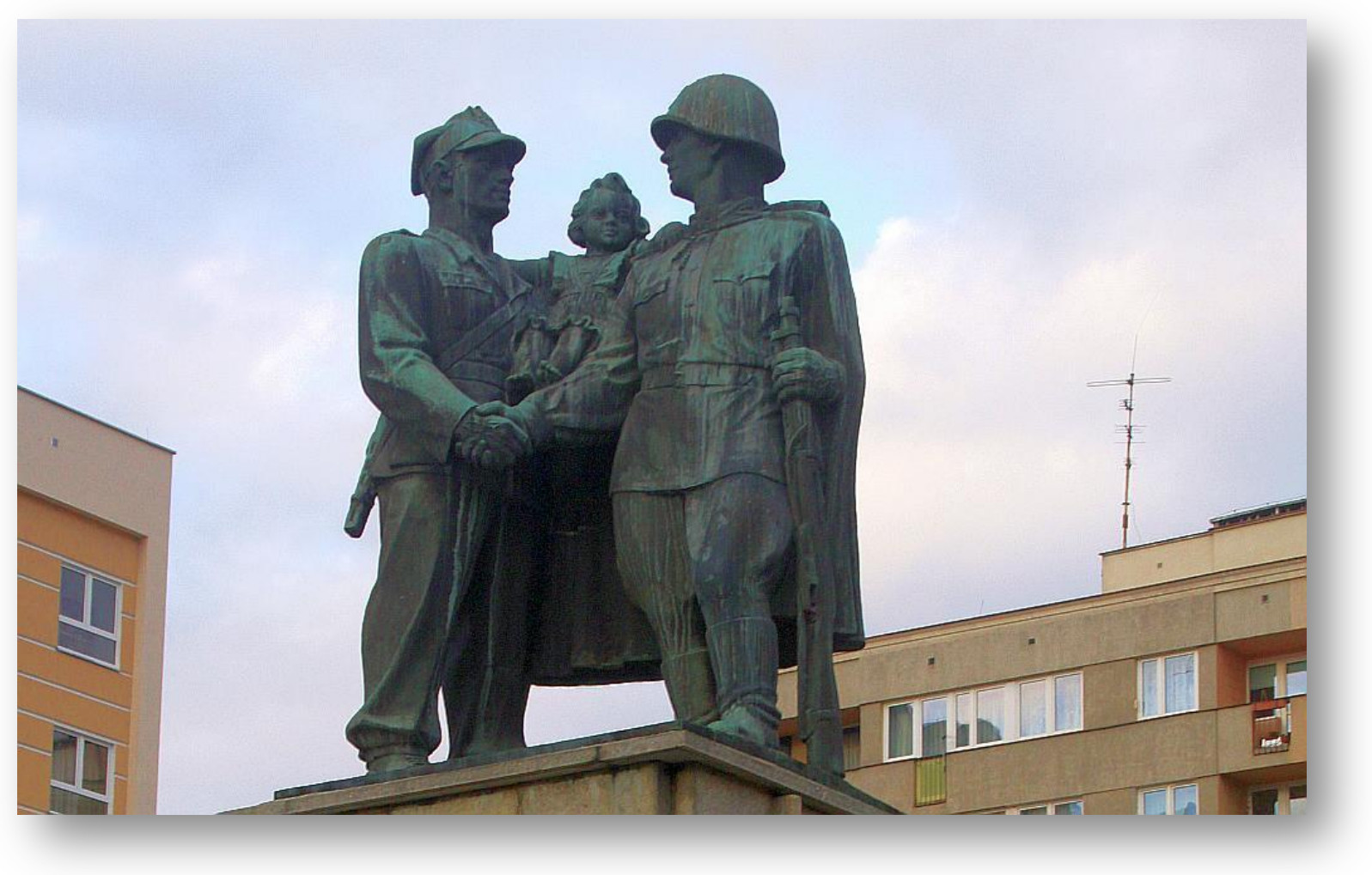

Figure 2: Monument of Gratitude to the Red Army ${ }^{92}$

Inscriptions on any monuments dedicated to the Katyń Massacre, which were seen as Soviet propaganda due to the false description on the plaque, were rewritten. ${ }^{93}$

92 Legnica, Plac Słowiański: Monument of Graditude to the Red Army Wojciech Obremski (Ica.pl) 
However, even these acts of altering or removing monuments could not completely erase the reminders of Soviet domination as many of the pedestals were not destroyed and many monuments have been and still are referred to as the new monument and the old monument, meaning the previous Soviet monument that was destroyed. Most of the Soviet monuments were destroyed during this period in the 1990's, but future conflict arose surrounding the Soviet monuments that were left intact. In 1994 the Russian Federation and Poland signed an agreement that Poland would not destroy any Soviet monuments or gravesites to avoid future contention over them. ${ }^{94}$

Examples like the movement of the Red Army Monument in the Kraków Military Cemetery in 1996 exemplify cooperation between Poland and the Russian Federation during this period.

\footnotetext{
${ }^{93}$ Any Katyń Massacre monuments, which were deliberately few, either attributed the crime to the Nazis or became a commemoration of both Polish and Red Army soldiers such as the Katyń Cross erected by the Soviets in 1985 in Powazki, a large war cemetery in Warsaw, were fixed from the Katyń lie or re-erected such as Melak's cross in 1995 which had been taken down by the Soviets in the 1980's. Etkind, "Remembering Katyn," 21.

94 "Umowa między Rządem Rzeczypospolitej Polskiej a Rządem Federacji Rosyjskiej o grobach i miejscach pamięci ofiar wojen i represji” Dziennik Ustaw Nr.112 Poz. 543, February 22, 1994.
} 
Figure 3: Red Army Monument in the Kraków Military Cemetery ${ }^{95}$

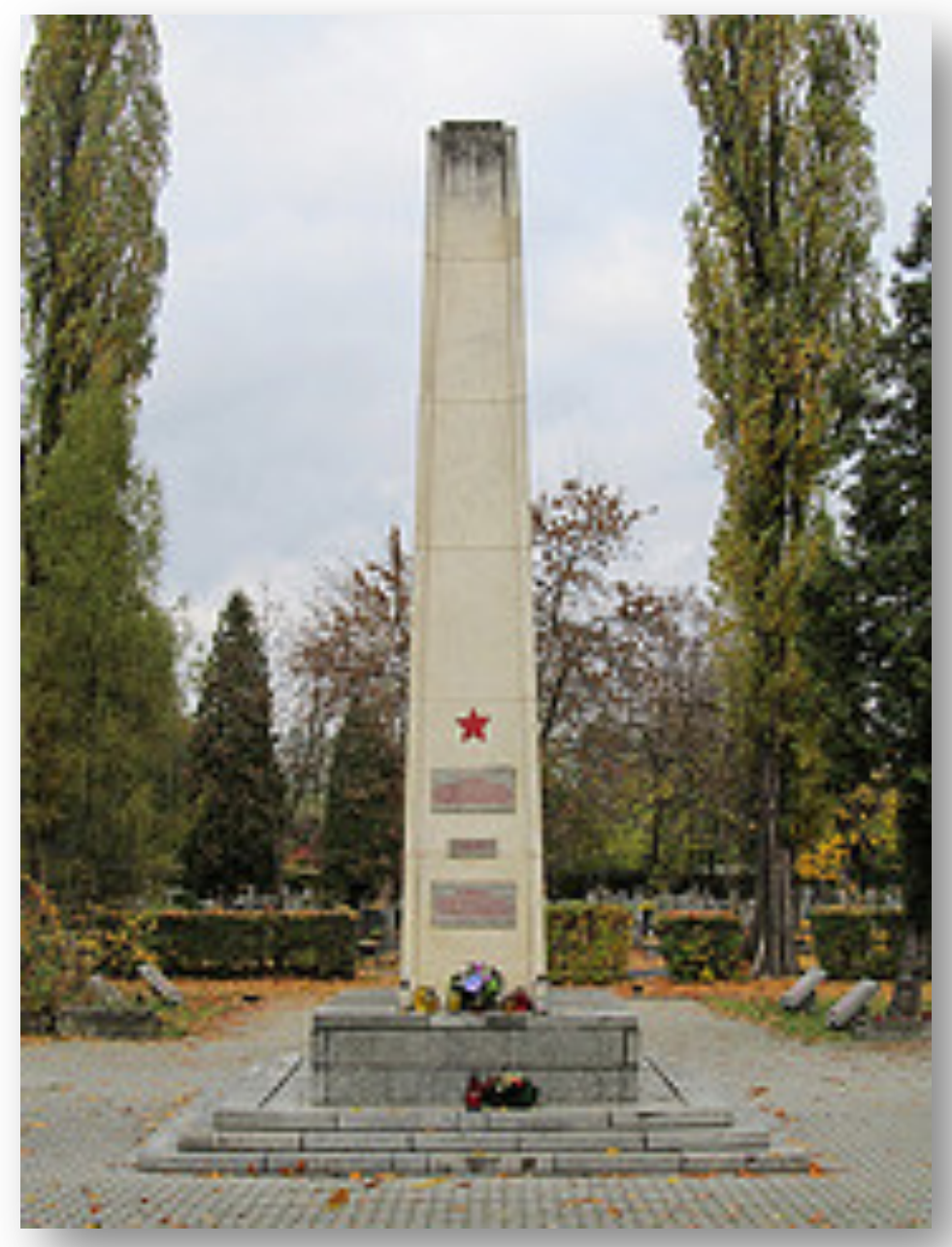

Although problems occurred over the moving of a Red Army monument in the center of Kraków because of the remains of soldiers attached to it, there was compromise. Poland received permission from the Russian Federation as well as Belarus, Ukraine, and Armenia to move soldiers remains to a famous military cemetery still in Kraków. After the agreement was reached, the monument and remains of soldiers were moved to the cemetery and the monument was placed

${ }^{95}$ Ochman. 
next to the Soviet officers, close to an Orthodox church. ${ }^{96}$ This is a successful example of the relocation of a monument and memorial through compromise between two states. Even with the multiple agreements between Poland and the Russian Federation and promise of mutual consultation, the monuments have again come to play a major role in the memory politics in contemporary Polish society, most recently in conjunction with the crisis in Ukraine.

The early 2000's began a period when Poles started to talk about how to hand troublesome issues from the past, including the leftover Soviet monuments. National memory reentered the public discussion after PiS began a politicized campaign in 2005 to "de-communize" the country and to "recover' Polish collective memory." 97 This campaign led to new legislation under a PiS government in 2007 on memorial sites that would strip all symbols of communism from them. ${ }^{98}$ Soviet monuments were quickly subjected to attention following the legislation and the campaign against these monuments was met with some opposition. There was not a major vocal public outcry to keep the monuments due to their original narrative, but many did not want to further disturb the peace between Poland and the Russian Federation, which already had a fragile relationship, and favored the thick-line approach focused on the future and economic cooperation. ${ }^{99}$ This can be observed from a poll in 2007 conducted by the Public Opinion Research Center (OPOB) where the majority of Poles wanted

\footnotetext{
${ }^{96}$ Ochman "Soviet War Memorials", 516.

${ }^{97}$ Ewa Ochman, "Soviet War Memorials and the Re-construction of National and Local Identities in Post-Communist Poland," Nationalities Papers, vol. 38 no. 4, (July 2010), 512.

${ }^{98}$ Ibid, 512.

${ }^{99}$ Ochman, "Soviet War Memorials," 513.
} 
monuments of Soviet soldiers to remain untouched. ${ }^{100}$ While the majority of Poles thought that the monuments should be left alone, when asked if the Soviet monuments represented symbols of liberation or "Polish enslavement," the results slightly favored the former by five percent. ${ }^{101}$

Although Polish elections returned a Civic Platform government, in December of 2011 PiS continued its fight in the Sejm projects to remove symbols of communism from public life. ${ }^{102}$ Its new proposed legislation aimed to remove communist symbols from street names, names of public buildings, and monuments because these symbols of communism "conflicted with a basic sense of justice and history." 103

Decisions to alter or displace monuments involving another state are always met with some fear of international conflict, in this case between Poland and the Russian Federation. Although the local governments were left in charge of deciding the fate of their monuments, the Sejm of the 1990's often blocked their decisions or took on the task of deciding the fate of Soviet monuments at

\footnotetext{
${ }^{100} 57$ percent wanted the Soviet soldier monuments to stay where they were while 28 percent thought that the monuments should be moved to a cemetery and eight percent thought that the monuments should be removed entirely. "Poll: Poles Want to Leave Soviet Soldiers Monuments" Newswire, May 26, 2007.

${ }^{101}$ In a survey conducted in May 2007 by TNS 38 percent of respondents thought that the monuments to Soviet Soldiers represented liberation while 33 percent of respondents felt that these monuments represented Polish enslavement. "Pomniki I Cmentarze Śołnierzy Radzieckich," TNS OBOP (Warsaw: May 2007).

102 "Poselski projekt ustawy o usunięciu symboli komunizmu z życia publicznego w Rzeczypospolitej Polskiej," Sejm, (2011), http://www.sejm.gov.pl/Sejm7.nsf/PrzebiegProc.xsp?nr=283 and "O usunięciu symboli komunizmu z życia publicznego w Rzeczypospolitej Polskiej," Sejm Rzeczypospolitej Polskiej Druk nr. 283 (Warsaw: December 12, 2011).

103 "Posłowie za usunięciem symboli komunizmu w Polsce," Gazeta Wyborcza, November 11, 2014.
} 
the state level if necessary in order to contain the impact on relations with Russia. Many Poles were in agreement with the government to leave many of the old monuments in place, even while building new monuments, in order to keep part of the painful past intact. ${ }^{104}$ However, the central governments since the 1990's have frequently met with nationalist opposition and many Soviet monuments have become vandalized in protest. Such acts have become more frequent since the early 2000 's, partly as a result of the Ukrainian crises that have divided the Russian Federation and Poland. This opposition also became more vocal as time continued and the future of the Soviet monuments has become a major political factor in contemporary Poland, particularly as populist parties like PiS have kept them in the spotlight. Even with an agreement signed with the Russian federation in 1994 in to assure the protection of Soviet graves and gravesites, those who are opposed to these symbols of the Soviet past are willing to risk breaking this agreement. Thus the tension between Polish national memory and the Soviet monuments continues to be controversial domestically and internationally. Sometimes agreements with Russia have been ignored or arbitrarily reinterpreted as in the case of the Polish-Soviet Comradeship monument in the capitol city of Warsaw.

\footnotetext{
${ }^{104}$ A survey in 2008 conducted by GfK Polonia found that sixty percent of Poles did not support the removal of Soviet monuments. Ochman, "Soviet War Memorials," 524.
} 


\section{WARSAW'S MONUMENT OF POLISH-SOVIET COMRADESHIP}

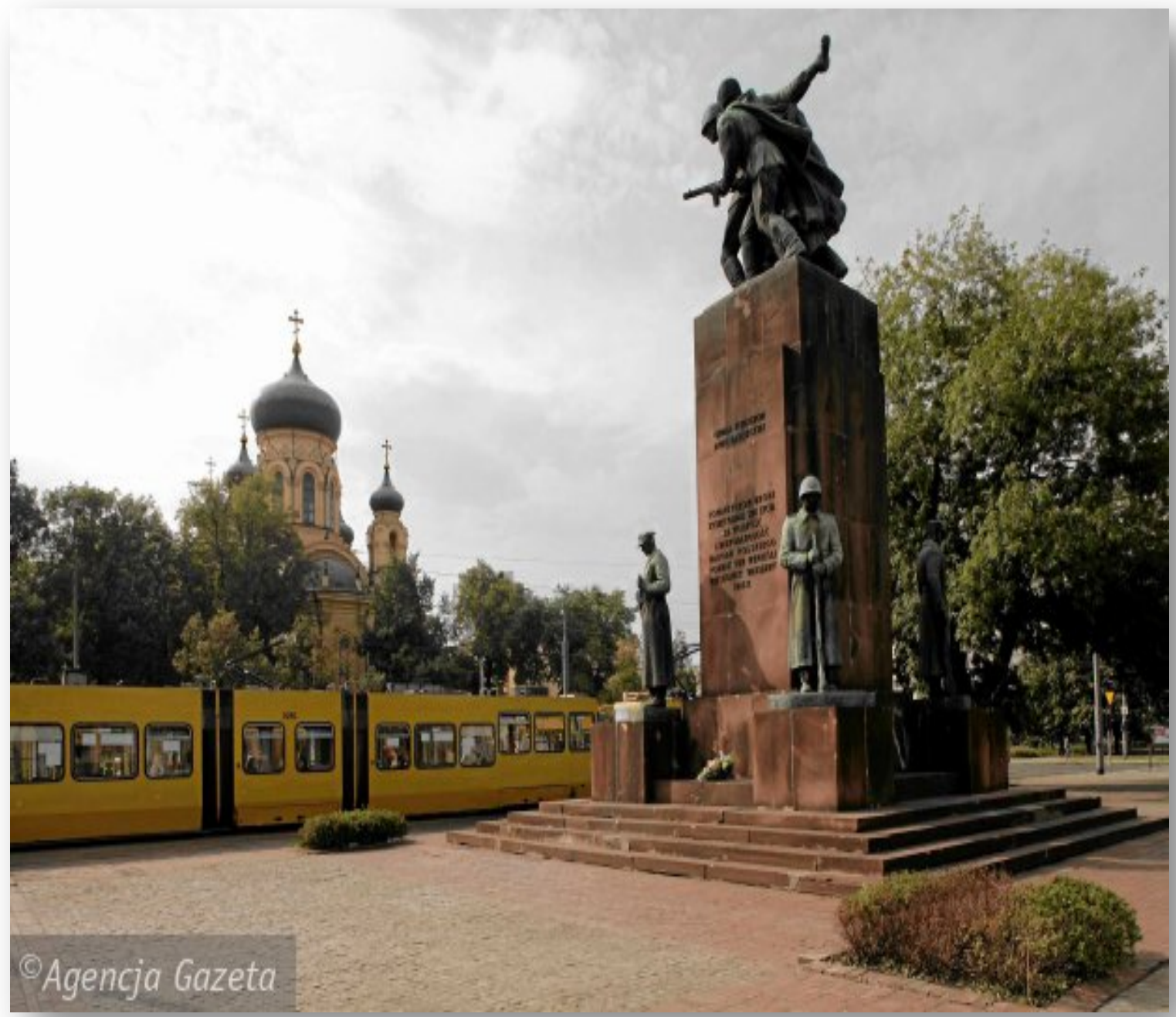

Figure 4: The Polish-Soviet Comradeship Monument in Warsaw before its removal. ${ }^{105}$

There are many cities and towns throughout Poland that exemplify the domestic tensions within Poland and the international tensions with the Russian Federation in handling Soviet monuments. Warsaw's monument of Polish-Soviet Brotherhood in Arms (Polsko-Radzieckiego Braterstwa Broni), also known as the "Four sleeping soldiers" or the Comradeship monument, however, is an important

105 Photo from Gazeta Wyborcza. 
example because of the recent nature of the conflict, the location of the monument in the capitol city of Poland, and the international attention that the removal of the monument has gathered. The debates and discussions surrounding this monument exemplify contemporary views of national memory in Poland. The deteriorating relationship between Poland and the Russian Federation and the role memory plays in both domestic and international politics.

In 1945 in Warsaw's Praga district the Soviets erected a monument to commemorate Poland and the Soviet Union's common fight against and defeat of the Nazis as well as to commemorate the many Red Army soldiers who died during the "liberation" of Poland. This monument was named the Monument of Polish-Soviet Comradeship, or Brothers-in-arms (Polsko-Radzieckiego Braterstwa Broni), and placed in the only part of Warsaw that had not been completely destroyed during the war, the Praga District across the Vistula River. ${ }^{106}$ The Polish-Soviet Comradeship monument stood throughout the period of Soviet influence in what is known today as Wilénski Square and reads, "Glory to the Soviet Army. To commemorate Comrades, who gave away their lives for the freedom and independence of Poland." ${ }^{107}$ The Comradeship Monument withstood the period of the 1990's when many Soviet monuments were destroyed or removed because of the efforts of Polish sculptors and architects to

\footnotetext{
106 The location itself plays a major role in memory politics when speaking about this monument. The Praga district was not completely destroyed because this is where the Red Army waited during the Warsaw Uprising and before launching its own attack on the Nazis. This in itself is controversial because of the time on the Praga side of the Vistula the Red Army stood by, while many Polish insurgents were dying in battle.

107 "Comradeship of the Sad and the Fighting: A History of Vanishing Monuments." Culture.pl, February 17, 2015.
} 
keep it in place. Discussion of removing the monument became more difficult for those who hoped to do so after 1994 when Poland signed an agreement with the Russian Federation agreeing not to destroy or remove any Soviet commemorative statues, graves or memorials. ${ }^{108}$

In 2011 with permission from the Russian Federation Warsaw moved the monument because of the construction of a new metro line to Praga. The conflict began with the planned return of the monument to its old spot in the center of the Praga district after the completion of the project, which some Warsaw residents protested, wanting the Soviet monument gone forever because of the narrative of domination this monument symbolized to these Poles. ${ }^{109}$ Mainly supporters of PiS, they thought the monument belonged in a museum of communism rather than in a major square in the capitol city of Poland. ${ }^{110}$ This narrative acquired large voice and influence because of the political, intellectual, and cultural figures that were stood behind it, not only within PiS, but across the political and cultural spectrum. These figures included economist Ryszard Bugaj and political scientist Marek Cichocki as well as celebrities like singer Antonina Krzysztoń and director Waldemar Krzystek to name a few. ${ }^{111}$ These intellectual and artistic figures of Poland wrote an open letter saying that almost two million złoty had been spent

\footnotetext{
108 "Umowa między Rządem Rzeczypospolitej Polskiej a Rządem Federacji Rosyjskiej o grobach i miejscach pamięci ofiar wojen i represji” Dziennik Ustaw Nr.112 Poz. 543, February 22, 1994.

109 "Warsaw City Councilors Ban 1945 Soviet Army Monument From Returning to a Warsaw City Square." U.S. News, February 27, 2015.

110 "Awantura o "czterech śpiących" na Radzie Warszawy. PiS nie chce też pomnika z parku Skaryszewskiego," Gazeta Wyborcza, February 12, 2015.

111“List otwarty w sprawie Pomnika Czterech Śpiących” Rzeczpopolia, September 4, 2014
} 
restoring this monument during its absence in the Praga district and while they "respected" the Russian soldiers who died liberating Warsaw, they did not want a monument "celebrating the invaders and rapists [the Soviet Union]." ${ }^{112}$ This open letter demanded that the monument should not be restored to a place of prominence in Warsaw because it symbolized Soviet oppression. ${ }^{113}$ Those who argued for the monument to return to the original location condemned the opposing narrative, arguing that the monument was a tribute to both Polish and Red Army soldiers and that there would be no contemporary independent Poland if not for the liberators this monument represents. ${ }^{114}$

In 2013 during the absence of the Comradeship Monument, the city council conducted a poll asking residents of Warsaw if the monument should be moved or returned to its original location. Only a small number of citizens responded, less than one thousand. However, $72 \%$ of those who did wanted the monument returned to its original location. ${ }^{115}$ Despite the results of this voluntary survey, the monument did not return once the metro line was completed in the autumn of 2014. Perhaps inspired by the decision about the fate of the Bronze Soldier in Tallinn, PiS proposed moving the monument to the Soviet military cemetery in Warsaw (Cmentarz Mauzoleum Żołnierzy Radzieckich). However, the chairman of the city council announced that they would vote against this proposal in order to keep "political jousting" out of the cemetery and the areas of

\footnotetext{
112 Ibid.

113 Ibid.

114 "Spór o pomnik "czterech śpiących" w Warszawie. Ambasada Rosji do "Wyborczej," Gazeta Wyborcza, March 10, 2015.

115 "Comradeship of the Sad and the Fighting: A History of Vanishing Monuments." Culture.pl, February 17, 2015.
} 
Ochota and Mokotów if the monument were removed to one of the cemeteries in these two Warsaw suburbs. ${ }^{116}$ The Russian Federation officially questioned Poland about the return of the Comradeship Monument after a vote of the Warsaw city council in February 2015, several weeks after the proposal by PiS, to keep the monument in storage.$^{117}$ The tension also continued between the two opposing memory narratives within Poland, even at times meeting on the street in protests. ${ }^{118}$

Tension has been recently building between the Russian Federation and Poland over the two different narratives represented by the Soviet monuments. Poland and Russia's political differences over Ukraine and sanctions have only added to the troubled relationship, and many Soviet monuments in Poland have been vandalized as a result. On February 28, 2015 the Russian Ministry of Foreign Affairs released a statement and demanded that Poland denounce what Russia called a "war on monuments." This statement expressed anger toward the Warsaw municipal authorities for their vote on the permanent removal of the Comradeship monument. The Russian statement reiterated the Soviet narrative of the monuments and called for explanations as to why so many Soviet monuments were being vandalized. ${ }^{119}$

\footnotetext{
116 "PiS proponuje: 'Czterech Śpiących' przenieść na cmentarz," Gazeta Wayborczej, February 4, 2015.

117 The Warsaw city councilors vote was 51-2 in favor of keeping the Comradeship Monument in storage. "Warsaw City Councilors Ban 1945 Soviet Army Monument From Returning to a Warsaw City Square." U.S. News, February 27, 2015.

118 "Uliczna kłótnia o pomnik "czterech śpiących" na Pradze," Gazeta Wyborcza, January 17, 2014.
} 
The Comradeship Monument is a great example of two conflicting narratives over a monument and the memory politics surrounding them. The recent nature of the controversy and its impact on Polish-Russian relations only confirms the importance of national memory, the layering of memory, and the meaning of monuments in memory politics. Memory has the power to enter politics and effect relationships between states, as seen in the case of the Comradeship Monument.

\section{CONCLUSIONS}

The Comradeship Monument in Warsaw is a contemporary and strong example of memory politics in Poland when speaking about the conflicting narratives that Soviet-era monuments have come to symbolize, particularly since the early 1990's. The narratives represented by the monument transcend marble and stone and, in the context of external conflicts resulting from Russia's annexation of Crimea and the war in eastern Ukraine, have further led to a souring of relations between Poland and with the Russian Federation. The conflicting narratives are so intensely argued and passionately represented by people because a narrative is connected to collective memory and therefore collective identity. Those arguing for the original narrative of the Soviet monuments typically have either a personal connection with the past represented by them, or they cannot accept PiS's version of Polish history and identity, which is seen as ultra-conservative and nationalistic. These voices are opposed by

\footnotetext{
119 "Комментарий МИД России в связи с ситуацией вокруг мемориальных объектов Второй мировой войны в Польше," Ministry of Foreign Affairs of the Russian Federation, February 28, 2015.
} 
those who argue that the Soviet monuments are a narrative of occupation and oppression, which should not be commemorated by physical symbols in "Polish" public space but instead should be purged from the Polish national landscape.

Like many sites of memory these monuments have also taken on the role of symbols of political contestation. Political parties in Poland propose different solutions to contemporary problems and use the monuments in different ways in order to promote their stance. Those on the left may argue that the monuments should be left untouched and that politics should be focused on the future rather than the past. More centrist parties may argue that the monuments should be moved to a Soviet cemetery or museum, while those on the right argue that the monuments should be eliminated completely. The issue of monuments or as Russia calls it, the "war on monuments," also shows how domestic disputes over historical memory in Poland can spill over into relations with Russia.

As the narratives continue to conflict over these Soviet monuments it is clear that the conflict between Poland and the Russian Federation will also continue to be affected by both memory politics and competing interests in the lands between them. It is evident from the examples of Soviet monuments in Poland that memory politics can influence state actions and can contribute to further contention between the two states, which in turn can have economic and national security repercussions that can fuel additional domestic political arguments within Poland. It is this intersection of memory and politics that has come to define Polish-Russian relations for the last quarter of a century. 


\section{Conclusion}

"I am sick of building our common identity around funeral marches and failed uprisings. I dream of Poland becoming a modern society that is defined not by the crippling nature of history, but by our individual achievements, a sense of our own self-worth and ideas for the future."-Olga Tokarczuk ${ }^{120}$

"The only solution is to acknowledge other people's memories and to negotiate a common past in which the sufferings of the other side and one's own share of the guilt have their proper place."-Jan Assmann ${ }^{121}$

Although Poland and the Russian Federation have not fully reconciled and have had their political differences it is evident that at times there have been signs of reconciliation through the example of the mutual commemoration of the Katyn Massacre in 2010 and subsequent events as well through the emergence of active reconciliation and open dialogue groups. There has been progress since 1989, though in fits and starts, and while total reconciliation might be years away, many positive steps were taken particularly in the period of 2007-2010, showing that reconciliation takes time and is possible. As stated by Olga Tokarczuk many Poles seek to move forward in order to become recognized as a key leader in the European Union and in international relations. This desire to move forward requires, as Jan Assmann states, a dialogue in sharing a common past and fully admitting wrongs where both sides are in agreement and while this has not been fully accomplished, it is not impossible for Poland and the Russian Federation. Although PiS won the presidential election in Poland in May 2015

\footnotetext{
120 "Where History's March is a Funeral Procession" The New York Times, April 15, 2010.

121 Jan Assmann, 21.
} 
there will still be those who wish to move forward in regards to Polish and Russian relations.

However, as seen in past relations between Poland and the Russian Federation the role of the lands between them, particularly the conflicts transpiring in the Ukraine will certainly play a part in Polish-Russian relations and therefore in shaping memory politics. As the Russian Federation continues to promote its interests in Ukraine while Poland tries to pull the Ukraine toward the West more tensions will arise and these tensions will inevitably spill over to memory politics. In turn any strong move in memory politics such as removing a Soviet monument, or as the Russian Federation has deemed it Poland's "war on monuments," will inevitably cause further tension with the Russian Federation and will spill over to relations between them. Both memory politics and international politics can and do affect one another.

Memory politics not only can play a role between two or more states but also interact with domestic political conflicts as seen by PiS's call for the "truth about Smolensk", or its version of the causes of the presidential plane crash of 2010. Parties and leaders can and do use memory politics to mobilize supporters and influence public opinion. Furthermore there will inevitably be different historical narratives and solutions proposed for handling the past as seen by the controversies and conflicts caused by leftover Soviet monuments in Poland as well as elsewhere in Central and Eastern Europe. However, if handled properly in constructive negotiations, such as occurred with the Gratitude to the Red Army monument in Kraków, the conclusion can satisfy both sides. 
As is evident from this study of Polish-Russian relations, memory and identity do in fact play a key role in this relationship. Not only does memory and identity play a role in the relationship between these two states but plays a role in international relations between all states that share a connected past. Constructivism argues that identity makes states more predictable and in turn makes the international system somewhat predictable in determining how states will act, but evident as well is how memory shapes this identity and how memory can affect foreign relations. However, it is clear that international relations can also have an effect on memory. Through the examples of the memory of an event like the Katyń Forest Massacre and or the memory attached to a monument one can see how memory can affect the international system and play a role in international politics and vice versa. Identities and memory with their history both play a role and explain how states interact with other states. States will always seek security, as Poland did in the early 1990's after the end of the Cold War, and the level of security achieved can affect whether a state's policy toward another state is cooperative or contentious. Regardless of the state memory of events in a historical relationship between two states, as seen in the case of Poland and the Russian Federation, plays a prominent role in politics because of their connected and often contested past. With collective memory playing such an important role in international politics it is clear that history certainly does matter in international relations. 


\section{Bibliography}

\section{Primary Sources}

Anders, Władysław. An Army in Exile: The Story of the Second Polish Corps. London: Macmillan, 1949.

“Andrzej Wajda pokazał “Katyń” w Moskwie," Gazeta Wyborcza, March 19, 2008.

"Awantura o "czterech śpiących" na Radzie Warszawy. PiS nie chce też pomnika z parku Skaryszewskiego," Gazeta Wyborcza, February 12, 2015.

"Can Russia and Poland Forget Centuries of Animosity in a Single Weekend?" Foreign Policy, April 16, 2010.

"Comradeship of the Sad and the Fighting: A History of Vanishing Monuments." Culture.pl, February 17, 2015.

"Convention for the Protection of Human Rights and Fundamental Freedoms," Council of Europe.

Crew Error Led to Polish Plane Crash, Russians Conclude," CNN, January 12, 2011.

"Did Tusk Go Soft on Russia?," The Economist, January 13, 2011.

"Фильм «Катынь»: Взрыв очередной антисоветской хлопушки," kprf.ru, April 9, 2010.

Grounded: Poland-Russia Relations," Carnegie Europe, April 13, 2015.

“"Катынь" Анджея Вайды в государственном телеэфире," gazeta kommersant, April 7, 2010.

“'Катынь' Вайды будет демонстрироваться в России," ИноСМИ, January 25, 2008

Katyń. Directed by Andrej Wajda. Poland: ITI Cinema, 2007.

"List otwarty w sprawie Pomnika Czterech Śpiących" Rzeczpopolia, September 4, 2014.

“Niech Katyń nas pojedna," Gazeta Wyborcza, April 8, 2010. 
"Приоткроет ли демонстрация фрильма Анджея Вайды "Катынь" завесу молчания над катынской трагедией?," svoboda, April 3, 2010.

"Россия увидит "Катынь"," svoboda, April 2, 2010.

"o usunięciu symboli komunizmu z życia publicznego w Rzeczypospolitej Polskiej," Sejm Rzeczypospolitej Polskiej Druk nr. 283, Warsaw, December 12, 2011.

"PiS proponuje: 'Czterech Śpiących' przenieść na cmentarz," Gazeta Wayborczej, February 4, 2015.

“Poland's Kaczynski Slams Russian Crash Report," Euronews, January 12, 2011

"Polish President Dies in Jet Crash in Russia," New York Times, April 10, 2010.

"Poll: Poles Want to Leave Soviet Soldiers Monuments" News Wire May 24, 2007.

"Polska i Rosja bliżej pojednania," Gazeta Wyborcza, April 8, 2010.

"Poselski projekt ustawy o usunięciu symboli komunizmu z życia publicznego w Rzeczypospolitej Polskiej," Sejm, (2011),

http://www.sejm.gov.pl/Sejm7.nsf/PrzebiegProc.xsp?nr=283

"Pomniki I Cmentarze Śłnierzy Radzieckich,” TNS OBOP (Warsaw: May 2007).

"Posłowie za usunięciem symboli komunizmu w Polsce," Gazeta Wyborcza, November 11, 2014.

"Putin Marks Soviet Massacre of Polish Officers." The New York Times, April 7, 2010.

"Russia is Still Burying the Truth about the Katyn Massacre." World Affairs Journal, October 29, 2013.

"Russia Takes Issue with Poland Over "Vandalism" at War Memorials." $B B C$, March 2, 2015.

"Russia Unable to Close Smolensk Crash Investigation due to Polish Inaction," Radio Poland, April 9, 2015.

"Russian Files Show Stalin Ordered Massacre of 20,000 Poles in 1940," The New York Times, October 151992.

"Spór o pomnik "czterech śpiących" w Warszawie. Ambasada Rosji do "Wyborczej" Gazeta Wyborcza, March 10, 2015. 
"Warsaw City Councilors Ban 1945 Soviet Army Monument From Returning to a Warsaw City Square." U.S. News, February 27, 2015.

"Warsaw's Second Metro Line Construction Completed." Radio Poland, September 30, 2015.

"W Sprawie Promocji Filmu "Katyń" w reżyserii Andrzeja Wajdy na terenie Rosji," Odpowiedź ministra kultury I dziedzictwa narodowego, May 14, 2008.

"Wzruszenie I cisza na "Katyniu” w Moskwie," Wprost, March 18, 2008.

"Ukraine Protests After Yanukovych EU Deal Rejection," BBC News, November 302013.

"Ukraine's Revolution: Making Sense of a Year of Chaos," BBC News, November 21, 2014.

"Uliczna kłótnia o pomnik "czterech śpiących" na Pradze" Gazeta Wyborcza, January 17, 2014.

"Umowa między Rządem Rzeczypospolitej Polskiej a Rządem Federacji Rosyjskiej o grobach i miejscach pamięci ofiar wojen i represji” Dziennik Ustaw Nr.112 Poz. 543, February 22, 1994.

"Where History's March is a Funeral Procession" The New York Times, April 15, 2010.

"Władimir Putin: Nie mamy prawa zostawiać następnym pokoleniom nieufność i wrogość," Gazeta Wyborcza, April 7, 2010.

“Wysoko oceniam przemówienie Putina," Gazeta Wyborcza, April 8, 2010.

"Yeltsin in Paris to sign NATO Agreement," CNN News, May 26, 1997.

Zdewastowany cmentarz: "Tusk chcemy prawdy," Gazeta Wyborcza, November 17, 2010.

\section{Secondary Sources}

Assmann, Aleida. "Transformations between History and Memory." Social Research, Vol. 75: No. 1, 2008.

Assman, Jan. Religion and Cultural Memory: Ten Studies. Stanford: Stanford University Press, 2006. 
Baran, Adam F., Grzegorz Motyka, Tomasz Stryjek and Rafal Wnuk. "The Soviet Underground-History, Memory and Politics." Warsaw: Muzeum II Wojny

Światowej, Instytut Studiów Politycznych, 2012.

Blatz, Craig W., Karina Schumann, and Michael Ross. "Government Apologies for Historical Injustices." Political Psychology. Vol. 30, No. 2, 2009.

Bloom William. Personal Identity, National Identity and International Relations. Cambridge: Cambridge University Press, 1990.

Cienciala, Anna M., Natalia S Lebedeva, Wojciech Materski. Katyn: A Crime Without Punishment. Yale University Press, 2008.

Esbenshade, Richard S. "Remembering to Forget: Memory, History, National Identity in Postwar East-Central Europe." Representations No. 49. (1995): $72-$ 96.

Etkind, Alexander, Rory Finnin, Uilleam Blacker, Julie Fedor, Simon Lewis, Maria Malksoo and Matilda Mroz. Remembering Katyn, Cambridge: Polity Press, 2012.

Fawn, Rick. Ideology and National Identity in Post-Communist Foreign Policies. London: Frank Cass Publishers, 2004.

Gillis, J. Commemorations: Memory and Identity. Princeton: Princeton University Press, 1995.

Goldman, Minton F. "Polish-Russian Relations and the 2004 Ukrainian Presidential Elections," East European Quarterly, XL No 4, 2006.

Gorska, Joanna A. Dealing with a Juggernaut: Analyzing Poland's Policy Towards Russia, 1989-2009. Lexington Books, 2012.

Halbwachs, Maurice. The Collective Memory. New York: Harper, 1980.

Hopf, Ted. "The Promise of Constructivism in International Relations Theory," International Security, Vol. 23, 1998.

Kansteiner,Wulf. "Finding Meaning in Memory: A Methodological Critique of Collective Memory Studies." History and Theory, Vol. 41, No. 2, 2002.

Kattago, Siobhan. "War Memorials and the Politics of Memory: the Soviet War Memorial in Tallinn" Constellations Vol. 16, No. 1 (2009).

Kowalska, W.M. "Is Policy of Memory Possible and How?" Limes, Vol. 1, No.1, (2008). 
Kubik \& M. Bernhard. Twenty Years after Communism: The Politics of Memory and Commemoration. Oxford: Oxford University Press, 2014.

Kattago, Siobhan. 2009. "War Memorials and the Politics of Memory: The Soviet War Memorial in Tallinn." Constellations 16, (1): 150-166.

Melchior, Inge, and Oane Visser. Voicing Past and Present Uncertainties: "The Relocation of a Soviet World War II Memorial and the Politics of Memory in Estonia." Focaal - European Journal of Anthropology.59 (2011): 33-50.

Mitchell, Katharyne. "Monuments, Memorials, and the Politics of Memory." Urban Geography 24 (2003): 442-59.

Ochman, Ewa. "Soviet War Memorials and the Re-Construction of National and Local Identities in Post-Communist Poland," Nationalities Papers. Vol. 38, No. 4, July 2010, 509-530.

Ochman, Ewa. Post Communist Poland-Contested Pasts and Future Identities New York: Routledge, 2013.

Olick, Jeffery K. "Collective Memory: The Two Cultures" Sociological Theory Vol. 17 No. 3, November (1999), 333-348.

Ozbay, Fatih. "Polish-Russian Relations: History, Geography and Geopolitics" Eastern European Quarterly, XLII, No. 1, March 2008.

Reinke, Max David. "Eastern Promises: Poland's Role as a Regional Actor in the European Union's Eastern Policy-The Example of Belarus," West Virginia University Libraries, 2012.

Sanford, George. "The Katyń Massacre and Polish-Soviet Relations, 1941-43," Journal of Contemporary History 41, 2006.

Snyder Jack L. Myths of Empire: Domestic Politics and International Ambition. New York: Cornell University Press, 1991.

Snyder, Timothy. "Memory of Sovereignty and Sovereignty over Memory: Poland, Lithuania and Ukraine, 1939-1999." Memory \& Power in Post-War Europe. Ed. Jan Werner Muller. Cambridge: Cambridge UP, 2002. 39-58.

Snyder, Timothy. Reconstruction of Nations: Poland, Ukraine, Lithuania, Belarus, 1569-1999 Yale: Yale University Press, 2003.

Wasilewski, Witold. "The Birth and Persistene of the Katyn Lie," Case Western Reserve Journal of International Law Vol. 45, 2013. 
Zawodny, J. K. Death in the Forest: The Story of the Katyn Forest Massacre University of Notre Dame Press, 1972.

Zawodny, Janusz. Nothing but Honour: The Story of the Warsaw Uprising, 1944 Stanford: Hoover Institution Press, 1978. 